\title{
Synthesis of novel olefin complexes of palladium( 0 ) bearing monodentate NHC, phosphine and isocyanide spectator ligands
}

\author{
L. Canovese $^{\mathrm{a}, *}$, F. Visentin ${ }^{\text {a }}$, T. Scattolin ${ }^{\text {a }}$, C. Santo ${ }^{\text {a }}$, V. Bertolasi ${ }^{b}$ \\ a Dipartimento di Scienze Molecolari e Nanosistemi, Università Ca' Foscari, Venice, Italy \\ ${ }^{\mathrm{b}}$ Dipartimento di Chimica e Centro di Strutturistica Diffrattometrica, Università di Ferrara, Ferrara, Italy
}

\section{A R T I C L E I N F O}

\section{Article history:}

Received 13 November 2017

Accepted 9 January 2018

Available online 31 January 2018

\section{Keywords:}

Olefin complexes of palladium(0)

$\mathrm{NHC}$

Phosphine

Isocyanide

Kinetic study

\begin{abstract}
A B S T R A C T
We have synthesized and characterized seventeen new bis-NHC, mixed NHC-phosphines or NHC-isocyanides $\operatorname{Pd}(0)$ olefin complexes that can potentially act as catalysts. The complexes were characterized by standard spectroscopic methods and elemental analysis and in two cases by SC-XRD technique. We have analyzed with particular care the thermodynamic and kinetic conditions governing the one-pot synthesis of the mixed complexes. In this respect we tried to validate our results by a dedicated computational study on the mutual distribution of the isomers that could be potentially formed. However, the computational result is not clear-cut owing to the not significant value of the calculated $\Delta \mathrm{G}_{0}$. Finally, in one case we have measured the rate of the exchange reaction between not particularly encumbered olefins.
\end{abstract}

(c) 2018 Elsevier Ltd. All rights reserved.

\section{Introduction}

Owing to their stability toward heat, moisture and air and their low toxicity [1], NHC ligands have been quite recently recognized as the real alternative to phosphines in the preparation of stable palladium catalysts [2]. Since the discovery [3] and the synthesis of the first stable NHC derivatives [4] the easy tune-up of the steric hindrance of the substituents at the imidazolic nitrogen [5] has allowed their detailed synthetic planning.

In addition, owing to the easy shift between the two reasonably stable oxidation states $\operatorname{Pd}(0)$ and $\operatorname{Pd}($ II $)$ [6], the use of palladium derivatives as homogeneous catalysts particularly in the field of the homo- and hetero-cross coupling is widespread [7]. Obviously, the performance of the catalyst can be improved by a wise structural planning which should induce a remarkable reactivity and an adequate stability throughout the turnover processes. A possible solution overcoming these conflicting features might be the synthesis of a $\operatorname{Pd}(0)$ pro-catalyst characterized by an easily displaceable olefin and stabilized by strong ligands. In such a way the labile olefin should promote the oxidative addition of organic halides, thereby triggering the overall catalytic process.

The characteristics of the palladium-olefin bond is clearly crucial since it represents a balance between the thermodynamic stability of the catalyst and its reactivity which is often kinetically controlled. [8].

\footnotetext{
* Corresponding author.

E-mail address: cano@unive.it (L. Canovese).
}

In this respect, we have prepared and fully characterized a number of palladium( 0 ) olefin bis-NHC, mixed NHC-phosphines or NHC-isocyanides derivatives to be tested as catalysts in future investigations. Notably, the one-pot synthesis of complexes bearing two different spectator ligands represents a remarkable and not trivial synthetic challenge, beside allowing the fine tuning of the electronic and steric features of the derivatives which are very important in planning catalysts [9]. We already came across a similar problem in the case of $\operatorname{Pd}(\mathrm{II})$ [10] and therefore we decide to extend our investigation to $\operatorname{Pd}(0)$ derivatives. In the following Scheme 1 we report the olefins and the starting thiopyridine palladium and silver carbene complexes described in the present paper.

\section{Results and discussion}

\subsection{General remarks}

The complexes 1a-d [11], 1e, 5a [12], 3 and 4 [13] were synthesized according to published procedures. The preparation of the imidaziolium salt 1,3-bis(4-methylbenzyl)-2,3-dihydro- $1 \mathrm{H}$-imidazole bromide and its derivative 2 will be described in Section 4 .

\subsection{Bis-carbene complexes}

In a previous paper [14] we have reported the synthesis and characterization of some palladium (0) bis-carbene complexes stabilized by maleic anhydride. It was apparent that the steric request of the carbene ligands and the nature of the starting palladium 

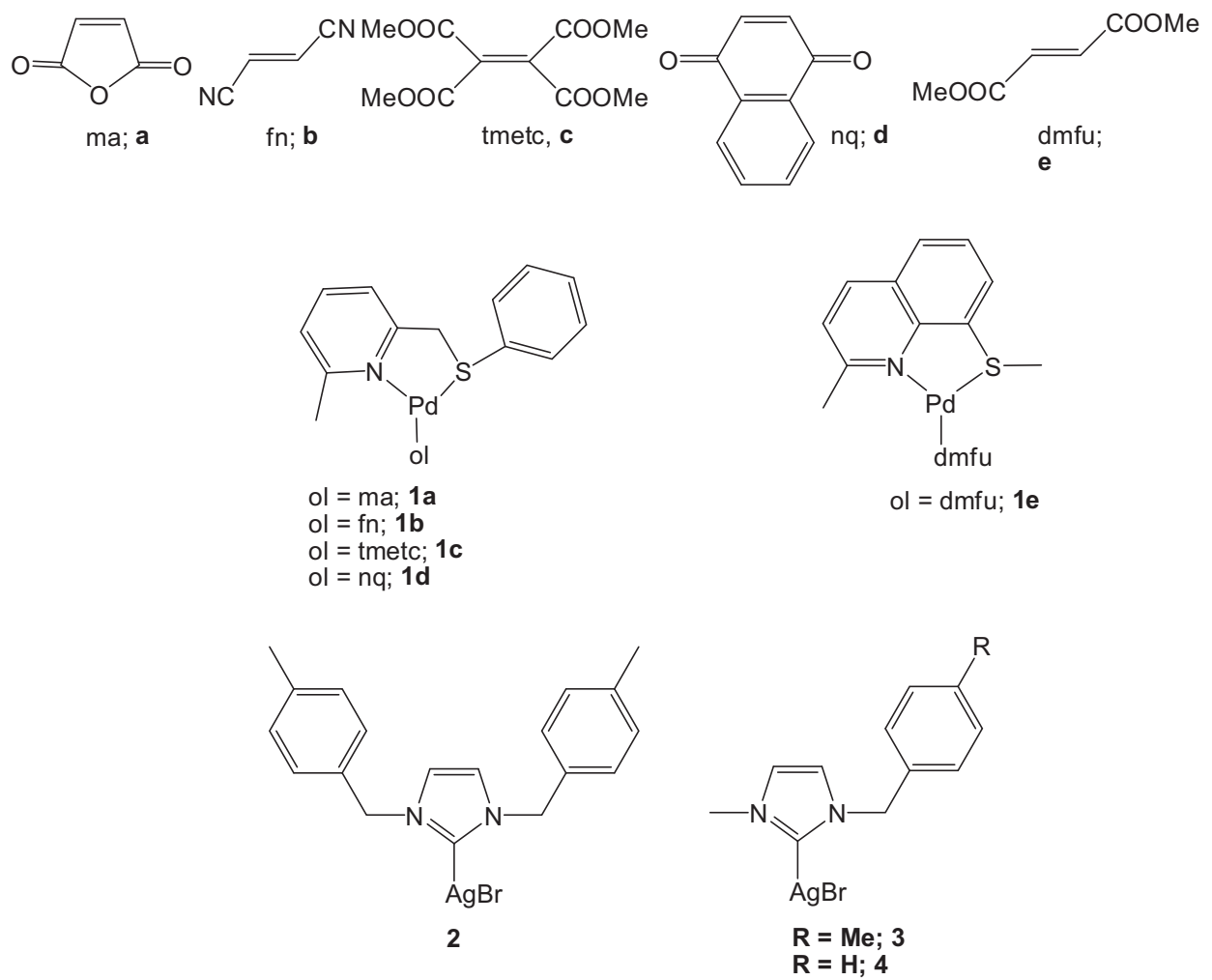

Scheme 1. Starting ligands and silver carbene complexes.

complexes did represent the critical point in the planning of the synthesis [10]. For such a reason, in order to carry out the transmetalation process, we have chosen derivative $2\left({ }^{1} \mathrm{H}\right.$ and ${ }^{13} \mathrm{C}\left\{{ }^{1} \mathrm{H}\right\}$ NMR spectrum in Fig. S1, Supplementary Material) and the complexes 1a-d as the palladium reactive species. As a matter of fact, on the basis of our experience, [14] the encumbered complex 2 could still react with derivatives $\mathbf{1 a}-\mathbf{d}$ characterized by the lability of the 2-methyl-6-(phenylthiomethyl)pyridine ligand to give the bis carbene species 5a-d [15]. The process yielding the derivatives $\mathbf{5 b}$-d is fast (10 min in the case of the most hindered $\mathbf{5 c}$ ) and the precipitation of $\mathrm{AgBr}$ indicates an almost immediate reaction. The ${ }^{1} \mathrm{H}$ NMR spectra of the complexes clearly point to the coordination of the olefin whose protons resonate as a singlet thanks to the equivalence of the ancillary ligands and at higher field than those of the uncoordinated alkenes. Such a feature is also confirmed by the ${ }^{13} \mathrm{C}\left\{{ }^{1} \mathrm{H}\right\}$ NMR spectra of the complexes displaying a marked upfield singlet $(\Delta \delta=70 \div 100 \mathrm{ppm}$ ) ascribable to the coordinated olefinic carbons. As for the carbene, the $\mathrm{AB}$ system related to the $\mathrm{C}_{2} \mathrm{~N}$ and the signals of the coordinated carbon at about 190 ppm are clearly observable. The consistent elemental analysis and the IR spectra complete the characterization of such species (see Section 4 and Fig. S2 in Supplementary Material).

\subsection{Mixed complexes, general considerations}

The direct synthesis of square planar complexes bearing two different monodentate spectator ligands is not always obvious. In order to obtain pure mixed species not contaminated by derivatives bearing the same two ancillary ligands it is necessary to meet a specific energetic condition. In particular the $\Delta \mathrm{G}^{\circ}$ of formation of the heteroleptic species must be reasonably lower than the $\Delta \mathrm{G}^{\circ}$ of formation of both the two species bearing the same ligands and therefore the thermodynamics of formation of the heteroleptic complex is crucial. In this respect it was suggested that such a condition can be obtained by the use of strong ligands possibly exerting an extra-stabilizing push and pull effect [9]. However, as was suggested in the case of palladium(II) derivatives, the kinetic aspect of the problem is not always negligible as can be deduced from the reactions describing the whole process [10a] summarized in Scheme 2:

As a matter of fact, under favorable thermodynamic condition we can have different results as a function of different combinations of the rates of the reaction reported in Scheme 2.

In this respect, it is worth noting that the processes involving the complex AgBrNHC are strongly conditioned by the complex nature of the transmetalation reaction [16] and therefore reaction 1 , which does not concern the transmetalation process but rather the exchange between ligands, is very probably the fastest one [10a,11a] (see Scheme 3).

Under this hypothesis we can envisage four different possibilities:

(i) Reaction 3 is faster than reaction 2. In this case we will observe the formation of the mixed complex only.

(ii) Reaction 2 is faster than reaction 3 and reaction 4 does not occur. In this case we will obtain the two bis-substituted species $\left[\mathrm{L}_{2} \mathrm{Pd}\left(\eta^{2}\right.\right.$-ol $\left.)\right]$ and $\left[(\mathrm{NHC})_{2} \mathrm{Pd}\left(\eta^{2}\right.\right.$-ol $\left.)\right]$.

(iii) The rate of reaction 3 is comparable with that of reaction 2 and reaction 4 does not occur. We will obtain all the species, i.e. two bis-substituted and one heteroleptic species in variable concentrations.

(iv) Reaction 4 occurs, the final species obtained will be again the mixed complex only independently of the rate of the reaction.

In order to verify whether the behavior observed in the case of $\mathrm{Pd}(\mathrm{II})$ complexes is generally valid, we tried to synthesize by direct 


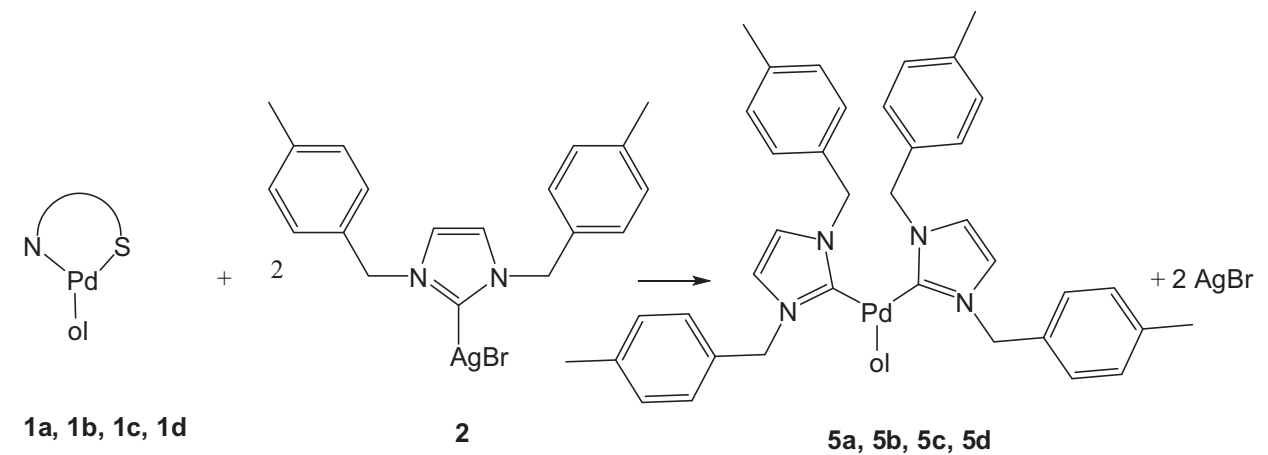

Scheme 2. Synthesis of the bis-carbene complexes.

$$
\begin{aligned}
& {\left[(\mathrm{N}-\mathrm{S}) \mathrm{Pd}\left(\eta^{2}-\mathrm{ol}\right)\right]+2 \mathrm{~L} \longrightarrow\left[\mathrm{L}_{2} \mathrm{Pd}\left(\eta^{2}-\mathrm{ol}\right)\right]+\mathrm{N}-\mathrm{S}} \\
& {\left[(\mathrm{N}-\mathrm{S}) \mathrm{Pd}\left(\eta^{2}-\mathrm{ol}\right)\right]+2 \mathrm{AgBrNHC} \longrightarrow\left[(\mathrm{NHC})_{2} \mathrm{Pd}\left(\eta^{2}-\mathrm{ol}\right)\right]+\mathrm{L}+2 \mathrm{AgBr}} \\
& {\left[\mathrm{L}_{2} \mathrm{Pd}\left(\eta^{2}-\mathrm{ol}\right)\right]+\mathrm{AgBrNHC} \longrightarrow\left[(\mathrm{L})(\mathrm{NHC}) \mathrm{Pd}\left(\eta^{2}-\mathrm{ol}\right)\right]+\mathrm{L}+\mathrm{AgBr}} \\
& {\left[\mathrm{L}_{2} \mathrm{Pd}\left(\eta^{2}-\mathrm{ol}\right)\right]+\left[(\mathrm{NHC})_{2} \mathrm{Pd}\left(\eta^{2}-\mathrm{ol}\right)\right] \longrightarrow 2\left[(\mathrm{~L})(\mathrm{NHC}) \mathrm{Pd}\left(\eta^{2}-\mathrm{ol}\right)\right]}
\end{aligned}
$$

\section{$\mathrm{N}-\mathrm{S}=$ 2-methyl-6-(phenylthiomethyl)pyridine or 2-methyl-8-(methylthio)quinoline}

Scheme 3. Reactions involved in the synthesis of mixed NHC-L palladium olefin complexes.

mixing of the reactants some palladium(0) olefin species stabilized by carbene-phosphine or carbene-isocyanide ligands (see Scheme 4).

\subsubsection{Mixed triphenyl phosphine-NHC complexes}

In this case we have promptly and exclusively obtained the mixed carbene-phosphine palladium olefin derivatives $\mathbf{6 a - e , 9 c}$ and 11c as a consequence of the concomitant addition of the reactants to the complexes 1a-e. Therefore, in the light of the above reported considerations we can safely suggest that reactions 1 and 3 are faster than reactions 2 and 4 . As for the rate of reaction 4 it is noteworthy that the mixing of the two homogeneously bissubstituted complexes does not yield the mixed derivatives in reasonable time (see Scheme 2).

Since it is not possible to synthesize the dimethylfumarate derivative stabilized by the ligand 2-methyl-6-(phenylthiomethyl)pyridine as starting material [8], in order to extend the range of the coordinated olefins to the labile dimethylfumarate, we have obtained the complex $6 \mathbf{e}$ starting from the complex 1e which bears the ligand 2-methyl-8-(methylthio)quinoline as spectator [17] (see Scheme 5).

In all cases, the almost immediate precipitation of $\mathrm{AgBr}$ indicated that transmetalation had occurred whereas a single peak within $27 \div 32 \mathrm{ppm}$ (as a function of the olefin) in the ${ }^{31} \mathrm{P}\left\{{ }^{1} \mathrm{H}\right\}$ NMR testified the coordination of the phosphine. However, the structural features of these complexes are clearly shown by their ${ }^{1} \mathrm{H}$ and ${ }^{13} \mathrm{C}\left\{{ }^{1} \mathrm{H}\right\} N M R$ spectra. Thus, all the signals belonging to the carbene are at different chemical shifts with respect to those of the starting silver complex and in particular the diastereotopic Tol- $\underline{\mathrm{C}}_{2}-\mathrm{N}$ protons resonate as an $\mathrm{AB}$ system or a couple of doublets. Similarly to type $\mathbf{5}$ complexes the signal of the two olefin protons of complexes 6 shifts downfield $(\Delta \delta \sim 3-4 \mathrm{ppm})$ with respect to those of the uncoordinated olefins. Remarkably both protons couple with phosphorus. In particular the proton trans to phosphine is characterized by a higher coupling constant. The ${ }^{13} \mathrm{C}$ $\left\{{ }^{1} \mathrm{H}\right\} N M R$ spectra confirm the structures of the complexes synthesized and in particular the carbon resonating at ca. $190 \mathrm{ppm}$ as a doublet owing to the proximity of the phosphorus proves the carbene coordination (see Fig. S3 Supplementary Material) (see Scheme 6).

Notably, in the ${ }^{1} \mathrm{H}$ NMR spectra at temperatures dictated by the nature of the complex under study, the doubling of the signals of the carbenic protons is observed. This fact can be traced back to the freezing of rotation about the Pd-C bond of the carbenic ligand which usually coordinates perpendicularly to the main plane of the complex. The frozen position of the carbene entails the duplication of the signals attributable to the mutual position of the carbenic and olefinic protons above and below the plane of the complex (see Fig. 1 and Fig. S3a,b Supplementary Material).

Not surprisingly, the freezing temperature of the complexes strongly depends on the steric request of the olefin and the presence of the bulky triphenylphosphine. Thus, complex $\mathbf{6 d}$ characterized by the encumbering naphthoquinone freezes at RT whereas a significantly lower temperature is necessary for the less sterically demanding derivatives.

Finally, we have been able to determine the solid state structure of a typical sample of this class of complexes with suitable crystals obtained by the slow freezing of a $\mathrm{CH}_{2} \mathrm{Cl}_{2}$-diethylether solution of complex 6d. An ORTEP [18] view of the $\mathrm{Pd}(0)$ complexes $\mathbf{6 d}$ is reported in Fig 2. A selection of bond distances and angles is given in Table SM1 (Supplementary Material).

The geometry around the Pd center is formally square planar and can be considered as trigonal planar if one takes the mid-point of the $\mathrm{C}=\mathrm{C}$ alkene double bond as the third coordination position.

In the complex $\mathbf{6 d}$ the palladium is bonded to the carbene carbon of a symmetrically substituted NHC ligand, the phosphorus of the triphenylphosphine group and $\mu^{2}$-coordinated to the C20-C21 

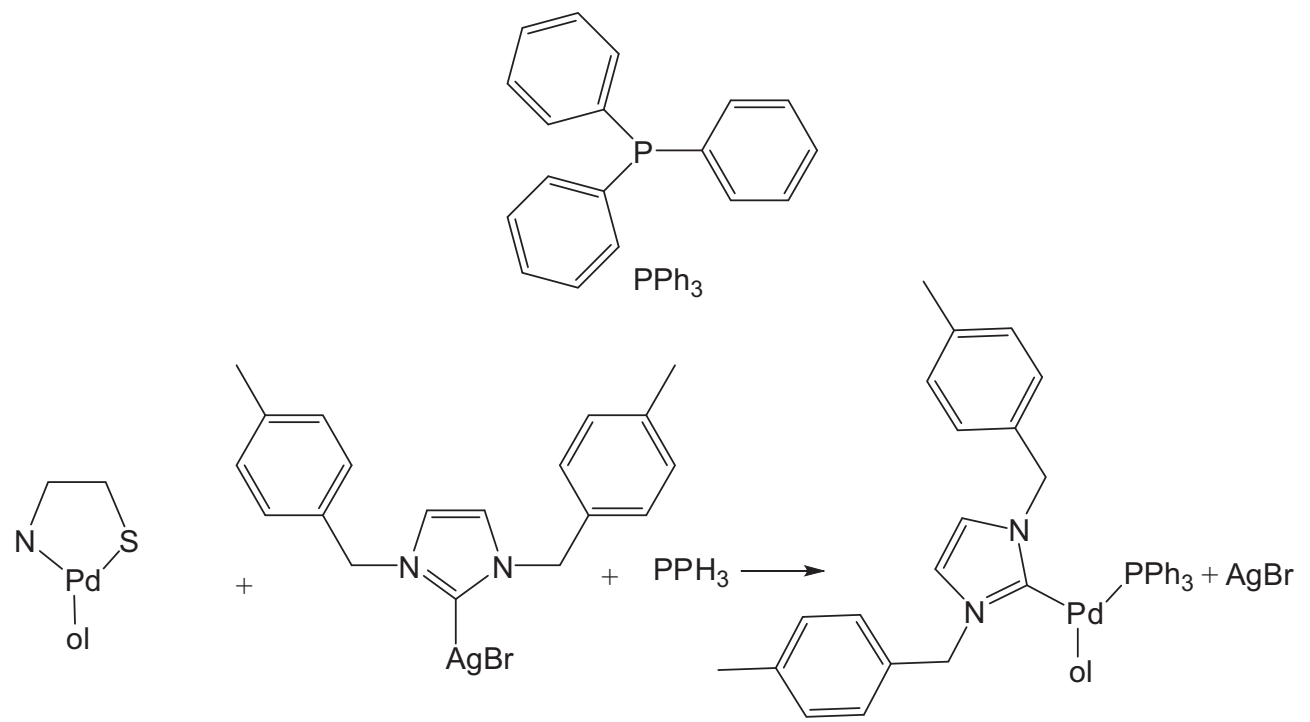

$1 \mathrm{a}, 1 \mathrm{~b}, 1 \mathrm{c}, 1 \mathrm{~d}, 1 \mathrm{e}$

2

$6 a, 6 b, 6 c, 6 d, 6 e$

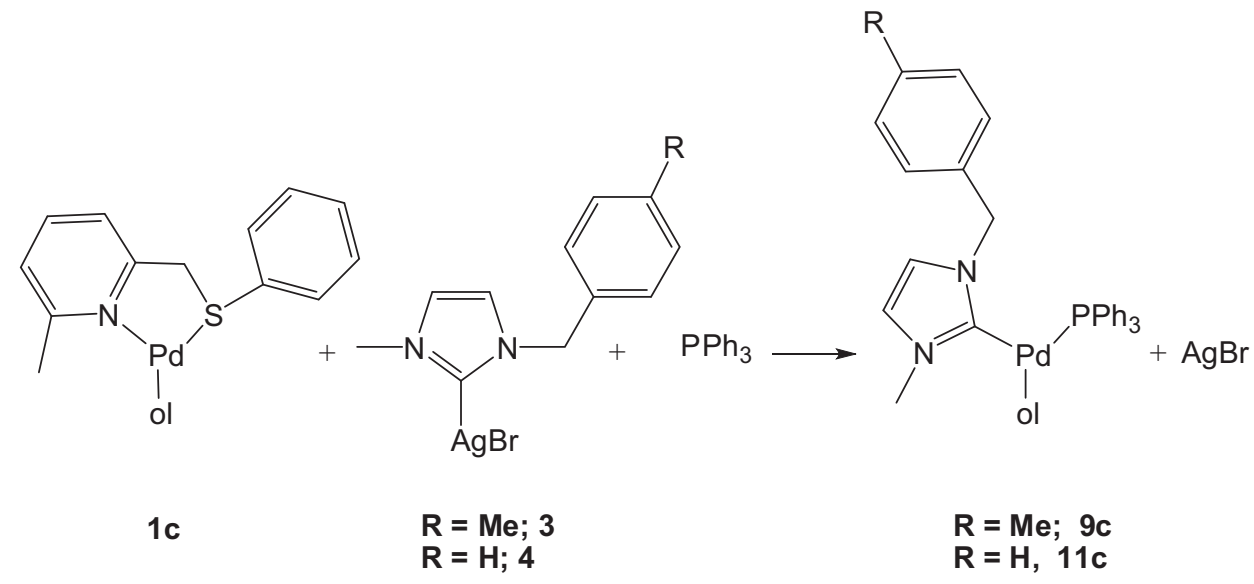

Scheme 4. Synthesis of the mixed NHC- $\mathrm{PPH}_{3}$ palladium olefin complexes.

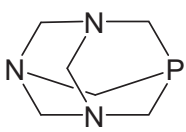

PTA

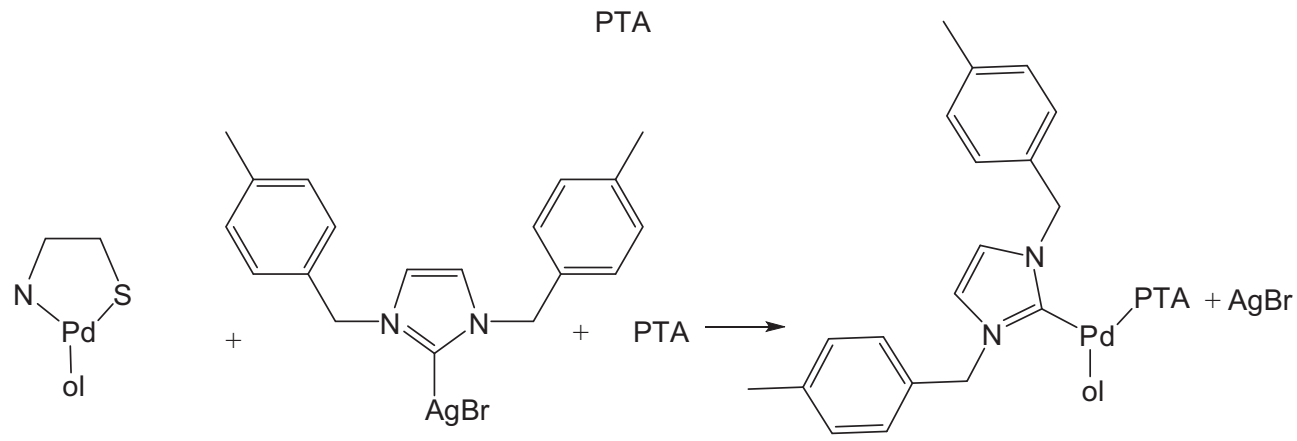

$1 a, 1 b, 1 c$

Scheme 5. Synthesis of the mixed NHC-PTA palladium olefin complexes. 


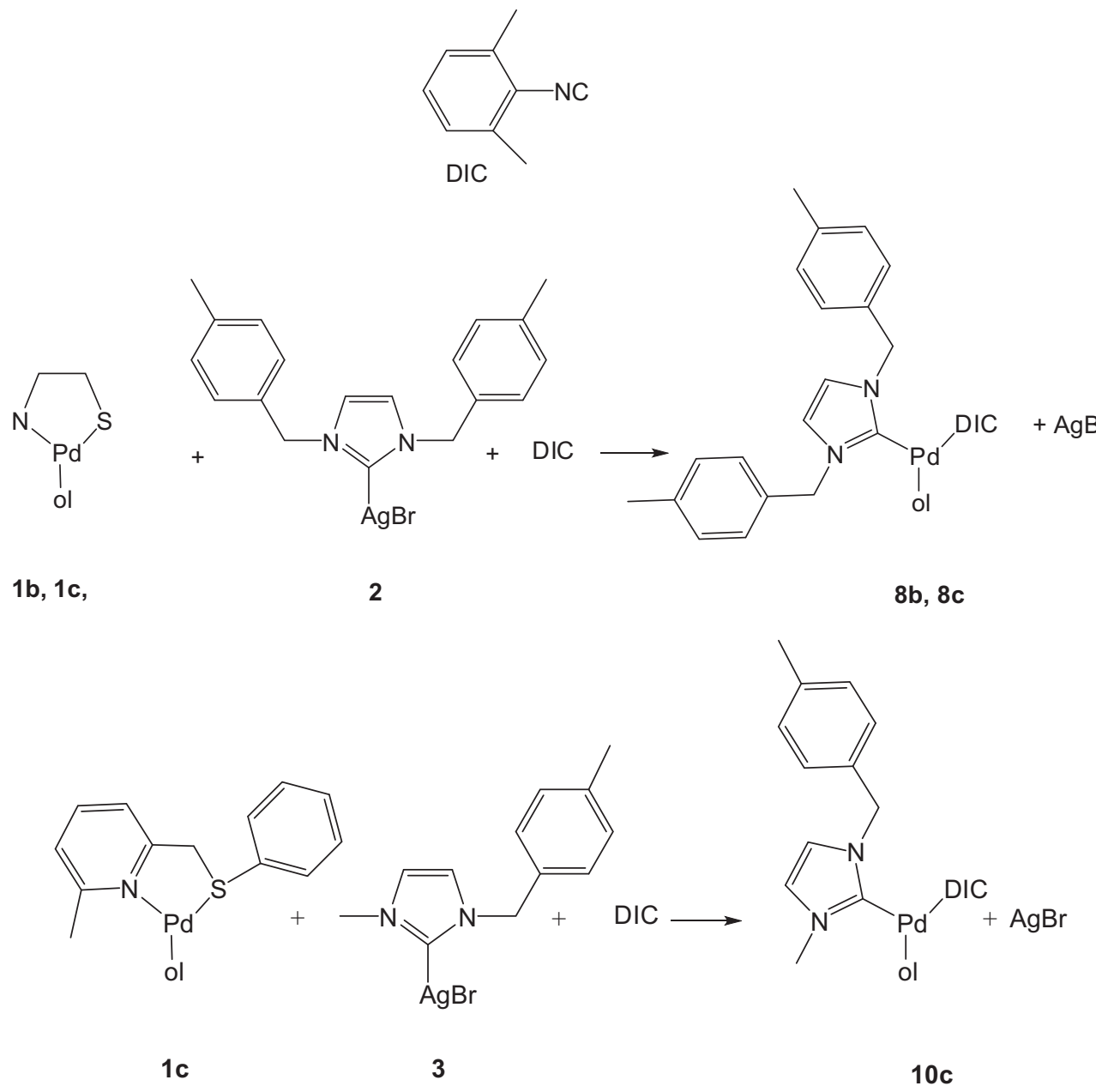

Scheme 6. Synthesis of the mixed NHC-DIC palladium olefin complexes.

double bond of the naphthalene-1,4-dione ligand. The $\mathrm{C} 20=\mathrm{C} 21$ double bond is lengthened to 1.435 (3) A. The mean plane of the naphthalene-1,4-dione is almost perpendicular to the mean coordination plane forming a dihedral angle of $88.68(4)^{\circ}$.

\subsubsection{Mixed PTA-NHC complexes}

In order to generalize and confirm the feasibility of the one-pot synthesis of mixed carbene-phosphine complexes we have carried out the preparation of palladium( 0 ) olefin complexes bearing one carbene and the phosphine 1,3,5-triaza-7-phospha-adamantane (PTA). Notably, PTA is a water soluble moiety and often its derivatives with the same feature have been used as green catalysts [19]. The synthetic protocol used with the mixed triphenyl phosphineNHC complexes described above gives super imposable results with complexes 1a-c whereas the reaction of complexes $\mathbf{1 d - 1 e}$ is characterized by general decomposition. The NMR spectra witness the exclusive formation of the title derivatives and in particular the ${ }^{31} \mathrm{P}\left\{{ }^{1} \mathrm{H}\right\}$ NMR spectra show a singlet in the interval $-57 \div-62 \mathrm{ppm}$ at ca. $40 \mathrm{ppm}$ downfield of the uncoordinated phosphine. The resonances of the $\mathrm{NCH}_{2} \mathrm{~N}$ and $\mathrm{NCH}_{2} \mathrm{P}$ groups of the PTA in the ${ }^{1} \mathrm{H}$ NMR and in general all the signals of the carbene moiety are also characteristic of the coordinated phosphine and carbene which moreover display an $\mathrm{AB}$ system related to the diastereotopic $\mathrm{Tol}-\mathrm{CH}_{2} \mathrm{~N}$ fragments. Remarkably, owing to the reduced bulkiness of PTA with respect of $\mathrm{PPh}_{3}$ no duplication of such signals is observed, indicating that the fluxionality of the systems cannot be frozen at any feasible temperature. Again, the carbenic carbon resonates in the interval of $187 \div 188 \mathrm{ppm}$ as a doublet and the $\mathrm{ABX}$ signals of the olefin are observed at lower field than those of the free alkenes (see Fig. S4 Supplementary Material).

\subsubsection{Mixed DIC-NHC palladium olefin complexes}

According to the hypothesis surmised so far [9] we have also tried to verify the feasibility of the one-pot synthesis of mixed isocyanide-carbene palladium(0) olefin complexes. Thus, we have reacted the derivatives 1a-c with 2-isocyano-1,3-dimethylbenzene (DIC) and the complexes $\mathbf{2}$ or $\mathbf{3}$. In the case of the reaction of complexes 1a and 1d we observed a general decomposition whereas complexes $\mathbf{1 b}$ and $\mathbf{1 c}$ give the mixed DIC-NHC derivatives $\mathbf{8 b}, \mathbf{8 c}$ and $10 \mathbf{c}$. However, in the case of the reaction of $\mathbf{1 b}$ with an equimolar mixture of DIC and $\mathbf{2}$, beside the complex $\mathbf{8 b}$ we noticed the formation of ca. $4 \%$ of both the bis-isocyanide species $\left[\mathrm{Pd}\left(\eta^{2}-\mathrm{fn}\right)(\mathrm{DIC})_{2}\right]$ and $\mathbf{5 b}\left(\left[\mathrm{Pd}\left(\eta^{2}-\mathrm{fn}\right)(\mathrm{NHC})_{2}\right]\right)$. We will discuss this peculiar case in the computational study section. As can be seen in Fig. 3 (See also Fig. S5 in Supplementary material) the structural features of the mixed complexes clearly emerge from the NMR data of the synthesized complex. In particular, the methyl groups of the isocyanide at ca. $2.2 \mathrm{ppm}$ and the $\mathrm{AB}$ system of the diastereotopic $\mathrm{CH}_{2} \mathrm{~N}$ are apparent in the ${ }^{1} \mathrm{H}$ NMR spectra.

Moreover, the ${ }^{13} \mathrm{C}\left\{{ }^{1} \mathrm{H}\right\}$ NMR spectra display weak signals of the coordinated isocyanide and the carbenic carbon at ca. 157 and 187 ppm, which respectively complete the identification of the reaction products. The slow freezing of a $\mathrm{CH}_{2} \mathrm{Cl}_{2}$-diethylether solution of complex $\mathbf{8 b}$ gave us the opportunity of determining also the solid 

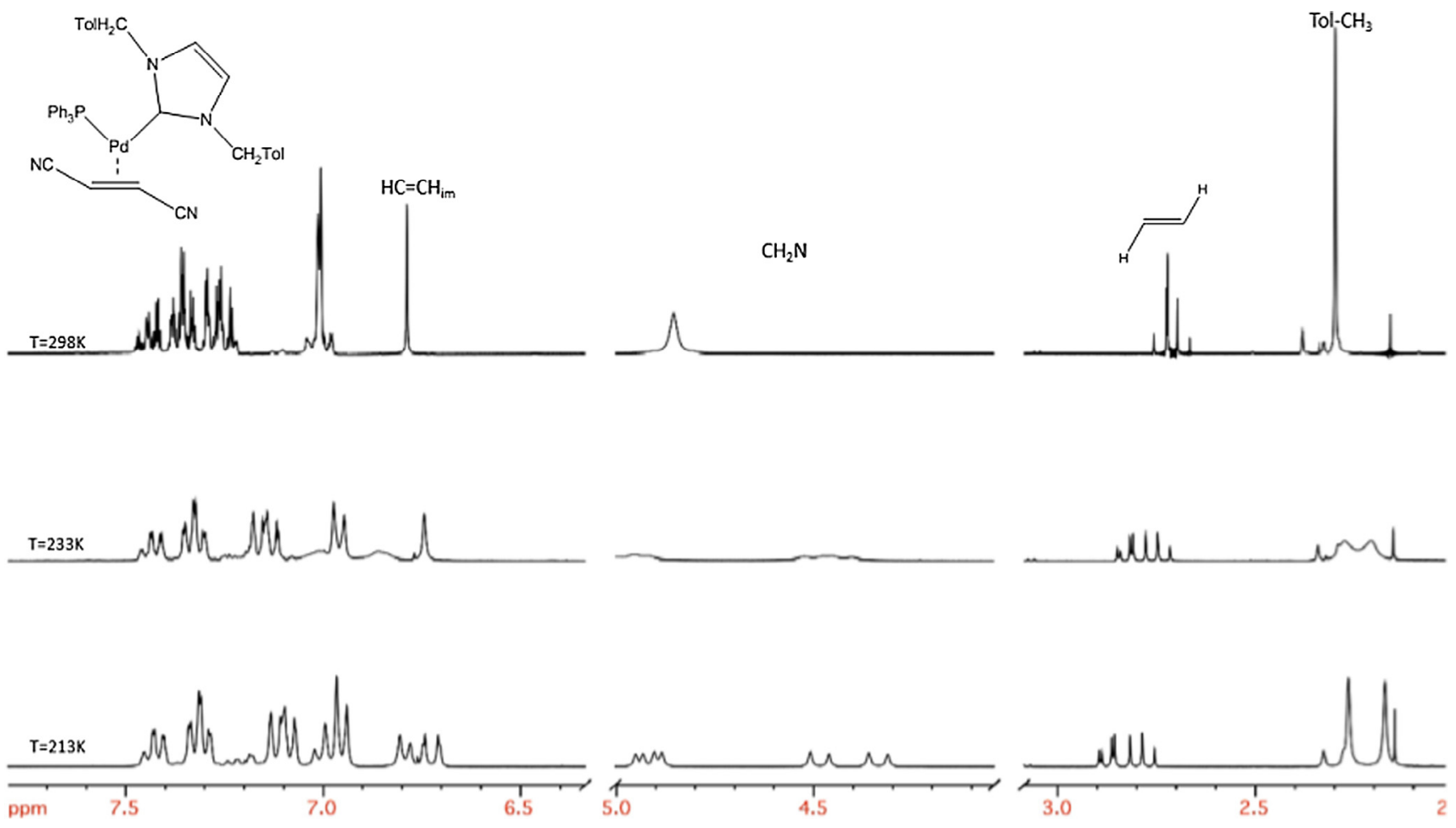

Fig. 1. ${ }^{1} \mathrm{H}$ NMR spectra of complex $\mathbf{6 b}$ in $\mathrm{CD}_{2} \mathrm{Cl}_{2}$ at different temperatures.

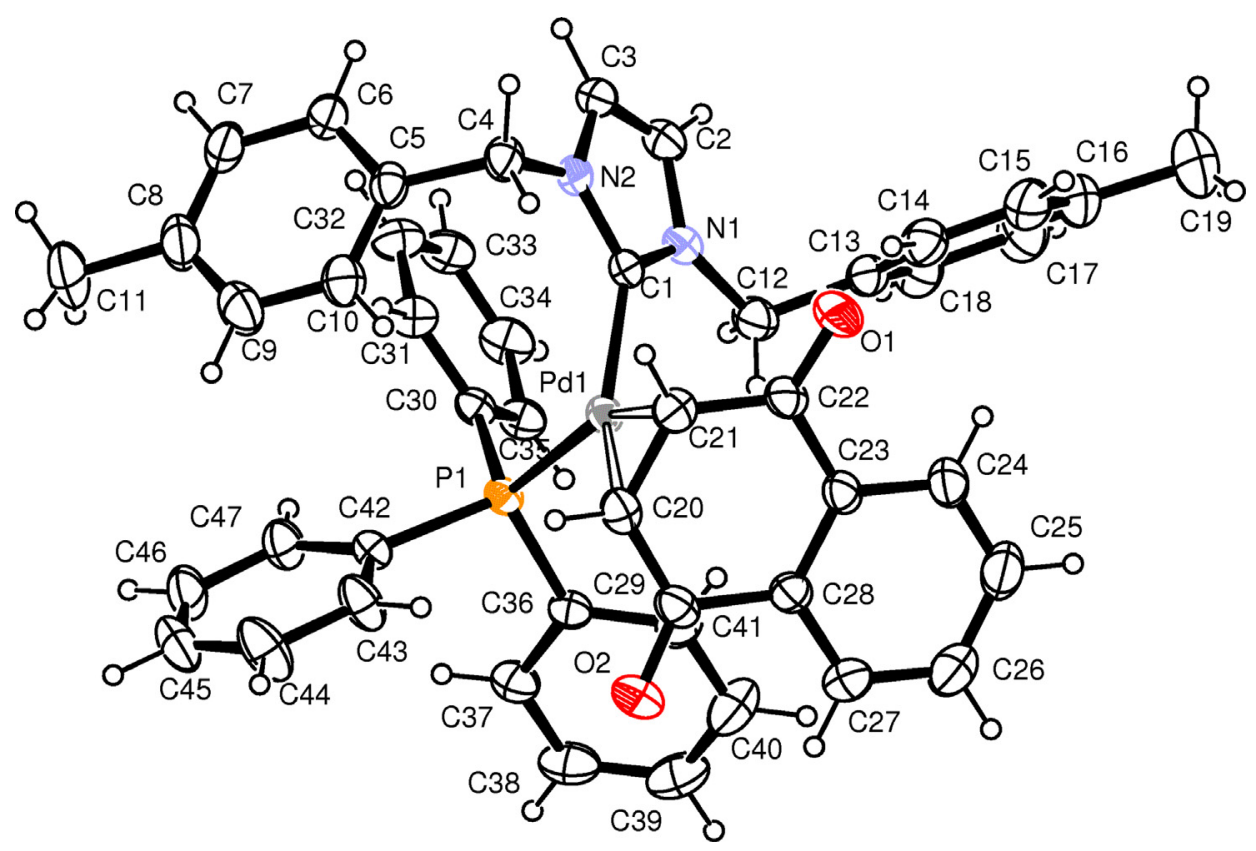

Fig. 2. ORTEP view of cationic complex $\mathbf{6 d}$ showing the thermal ellipsoids at $30 \%$ probability level.

state structure of an example of these mixed compounds. Also in this case the geometry around the Pd center is formally square planar and can be considered as trigonal planar if one takes the midpoint of the $\mathrm{C}=\mathrm{C}$ alkene double bond as the third coordination position. In complex $\mathbf{8 b}$ the palladium is bonded to a symmetrically bis-substituted NHC ligand through the carbene carbon, to the isocyanide carbon of the (2,6-dimethyl-phenyl)-isocyanide ligand and the $\mu^{2}$-coordinated $\mathrm{C} 20-\mathrm{C} 21$ carbons of the carbene group of 2(E)-but-2-ene-dinitrile ligand, thanks to the $\mathrm{C}=\mathrm{C}$ alkene group. The mean molecular plane of this ligand is rotated by 87.0 $(5)^{\circ}$ with respect to the Pd coordination plane. The C22-C21-C20-C23 carbon chain is slightly twisted by a torsion angle of $-145.4(2)^{\circ}$ and the $\mathrm{C} 20=\mathrm{C} 21$ double bond is lengthened to 1.441 (3) A (Fig. 4). 


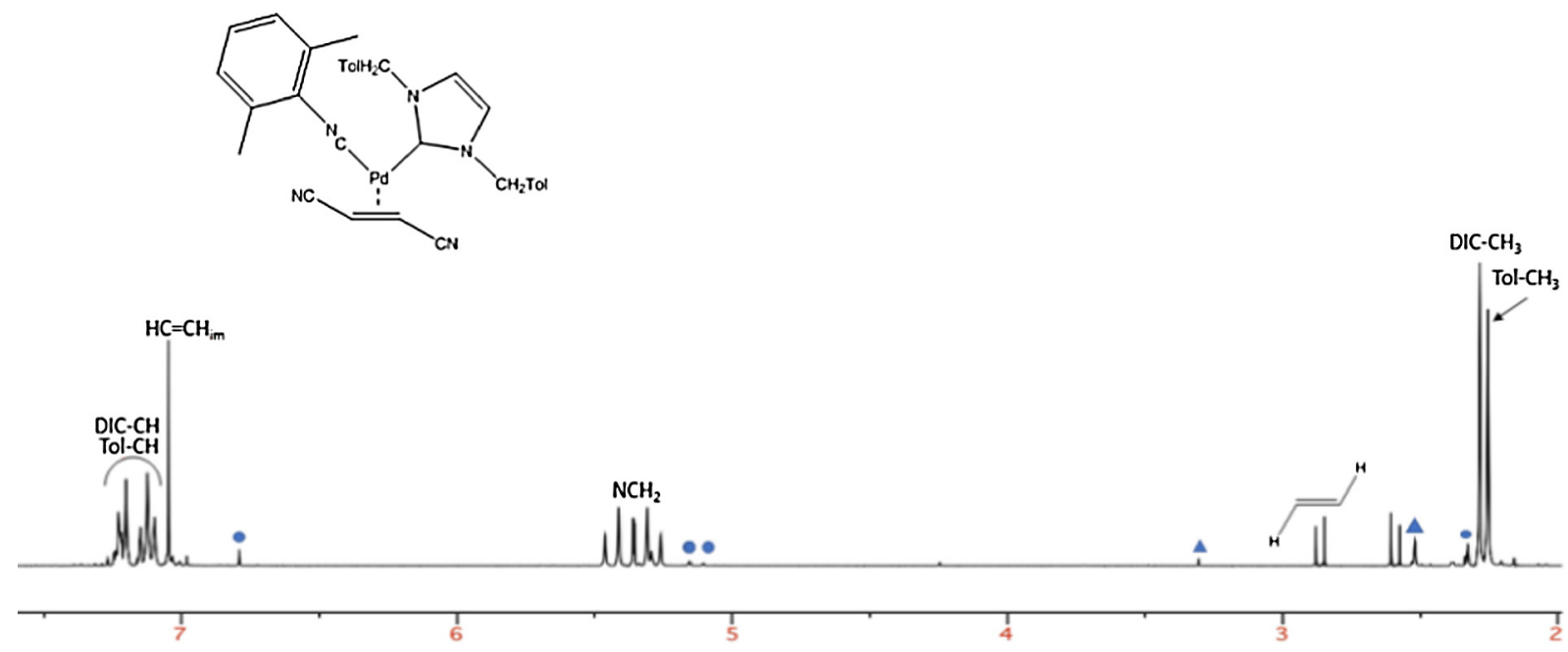

Fig. 3. ${ }^{1} \mathrm{H}$ NMR spectrum of complex $8 \mathbf{b}$ in $\mathrm{CD}_{2} \mathrm{Cl}_{2}$ at $298 \mathrm{~K} . \Delta\left[\mathrm{Pd}\left(\eta^{2-} \mathrm{fn}\right)(\mathrm{DIC})_{2}\right]$.

\subsection{Computational study}

On the basis of theoretical calculations performed with the Gaussian 09 package [20] (see Section 4 for computational details) we were able to calculate the $\Delta G_{0}$ values related to the reaction 4 in Scheme 2 with $\mathrm{L}=\mathrm{PPh}_{3}$ and DIC, respectively. The $\Delta \mathrm{G}_{0}$ value was $2.64\left(\mathrm{~L}=\mathrm{PPh}_{3}\right)$ and $\left.2.44 \mathrm{kcal} / \mathrm{mol}(\mathrm{L}=\mathrm{DIC})\right)$. The positive calculated $\Delta \mathrm{G}_{0} \mathrm{~s}$, both indicate an unfavourable reaction progress since the formation of the mixed species is about 5 or $6 \%$ of the initial concentration of the starting homogeneously bis-substituted species assumed equimolecular (see Eq. (4) in Scheme 2). However, owing to the uncertainty affecting this sort of calculation (almost equivalent in extent to the calculated $\Delta G_{0}$ values $\pm 2 \mathrm{kcal} / \mathrm{mol}$ ), no definitive conclusions can be drawn. We can only surmise that when a strong competition among $\pi$-electron accepting ligands on palla$\operatorname{dium}(0)$ complexes (DIC isocyanide and fumaronitrile) a complex distribution among the possible species is probable and possible.

\subsection{Kinetic study}

In order to assess and confirm the mutual stability between palladium (0) olefin complexes we decided to study kinetically the reaction reported in Scheme 7:
Owing to the unusually slow reaction rate (this sort of reactions entailing the exchange between napthoquinone and maleic anhydride are almost always very fast [11]) we have carried out our investigation by UV-Vis spectrophotometric technique. In our case complex 6d shows an acceptable solubility and its absorbance principally ascribable to the napthoquinone chromophore provides an adequate absorbance change for the reaction in Scheme 7. Therefore, this study represents the first case of a slow reaction rate involving the exchange between the not particularly hindered olefins maleic anhydride and napthoquinone.

As shown elsewhere by the direct determination of the equilibrium constants by direct titration of the napthoquinone derivatives with maleic anhydride, the latter is a better coordinating moiety toward $\operatorname{Pd}(0)$ than napthoquinone. Although their mutual stability (measured as $\mathrm{Ke}=$ [maleic anhydride complex][napthoquinone]/ [napthoquinone complex][maleic anhydride]) is strongly affected by the nature of the spectator ligands, spanning between 4.5 and $630,[8,21]$, a favorable concentration ratio between complex $\mathbf{6 d}$ and maleic anhydride (in this case $[\mathrm{ma}] /[\mathbf{5 d}] \geq 10$ ) usually ensures the complete displacement of napthoquinone. Moreover, under the adopted experimental conditions the observed changes of absorbance versus time obey the monoexponential equation:

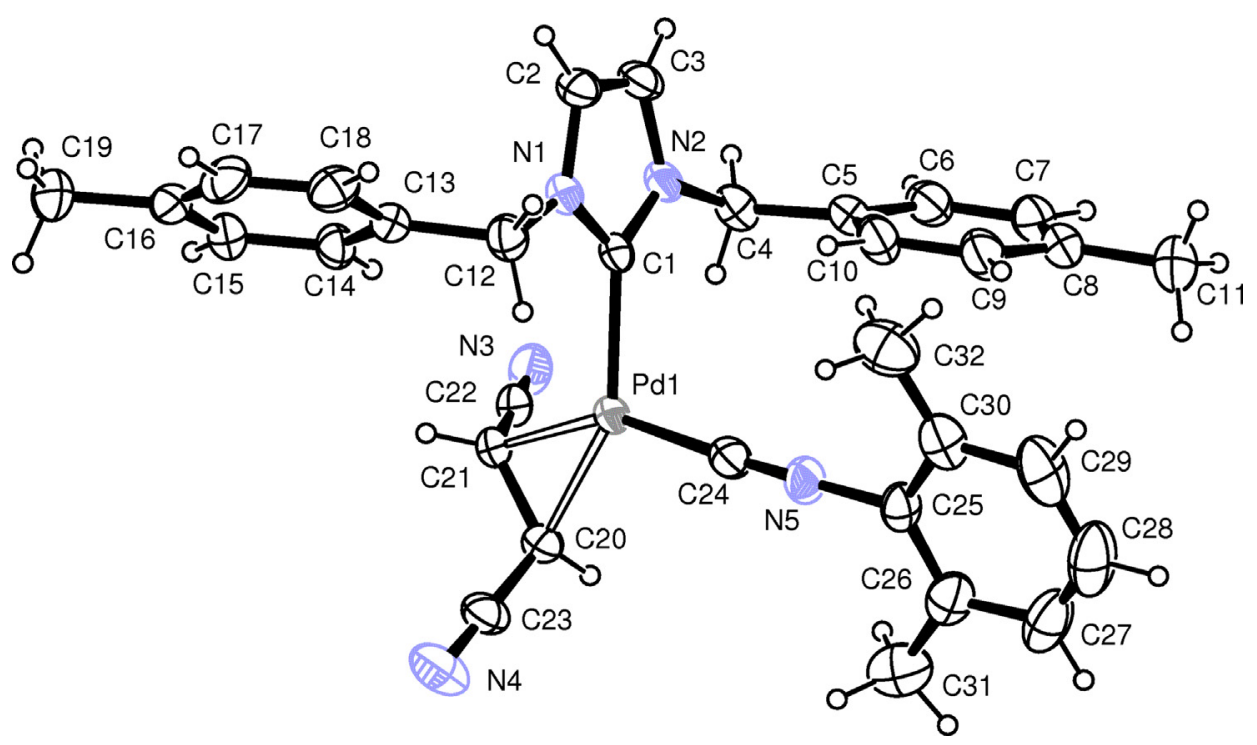

Fig. 4. ORTEP view of cationic complex $\mathbf{8 b}$ showing the thermal ellipsoids at $30 \%$ probability level. 
<smiles>O=C1C=CC(=O)O1</smiles>

$6 d$<smiles>C/C=C(\CC)C1N(C[Te+])C=CN1COO</smiles>

$6 a$

Scheme 7. Reaction studied under kinetic conditions.

$A_{t}-A_{\infty}=\left(A_{0}-A_{\infty}\right) e^{-k_{o b s} * t}$

where $A_{0}, A_{\infty}$ and $A_{t}$ represent the initial, the final and absorbance at time $t$, respectively (Fig. 5).

The monoexponential dependence testifies that the return reaction (with a second order dependence on the displaced napthoquinone concentration) is negligible and that the whole process can be described by the relationship:

$-\mathrm{d}[\mathbf{5 d}] / \mathrm{dt}=\mathrm{k}_{2}[\mathbf{5 d}][\mathrm{ma}] ; \mathrm{k}_{2}[\mathrm{ma}]=\mathrm{k}_{\mathrm{obs}}$

The final spectra of the reactions investigated under the mentioned experimental conditions are coincident with those of the authentic product or mixture of products independently prepared. The calculated $\mathrm{k}_{\mathrm{obs}}$ represents the pseudo first order rate constant and depends linearly on the concentration of maleic anhydride (Fig. 6).

Linear regression of $k_{\text {obs }}$ versus [ma] yields the second order rate constant $k_{2}\left(k_{2}=117 \pm 3 \mathrm{~mol}^{-2} \mathrm{dm}^{3} \mathrm{~s}^{-1}\right)$ which is ascribable to a typical associative mechanism involving the formation of a bis-olefinic 18-electron activated state. The adopted methodology is described in details in Section 4 whereas the changes of absorbance at different wavelengths versus time, one example of the monoexponential fit of absorbance versus time at a fixed wavelength and the linear regression of $\mathrm{k}_{\mathrm{obs}}$ versus [maleic anhydride] are reported in Fig. S6 of Supplementary Material whereas.

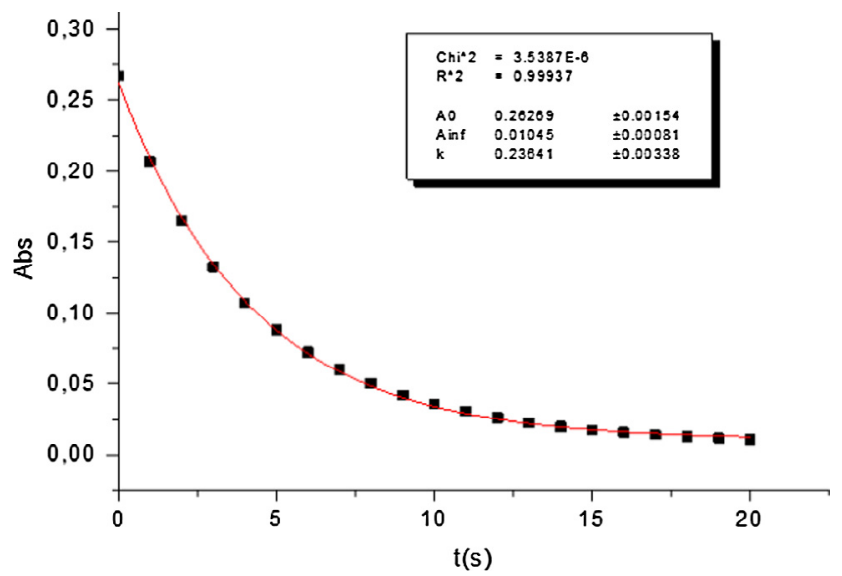

Fig. 5. Absorbance $v s$. time and non linear regression analysis $(\lambda=416 \mathrm{~nm}, T=298$ in $\mathrm{CHCl}_{3}$; reaction: $\mathbf{6 d}+\mathrm{ma} \rightarrow \mathbf{6 a}+\mathrm{nq} ;[6 \mathrm{~d}]=8 \times 10^{-5} \mathrm{~mol} \mathrm{dm}{ }^{-3}$, [ma] $=2 \times 10^{-3}$ $\mathrm{mol} \mathrm{dm}{ }^{-3}$ ).

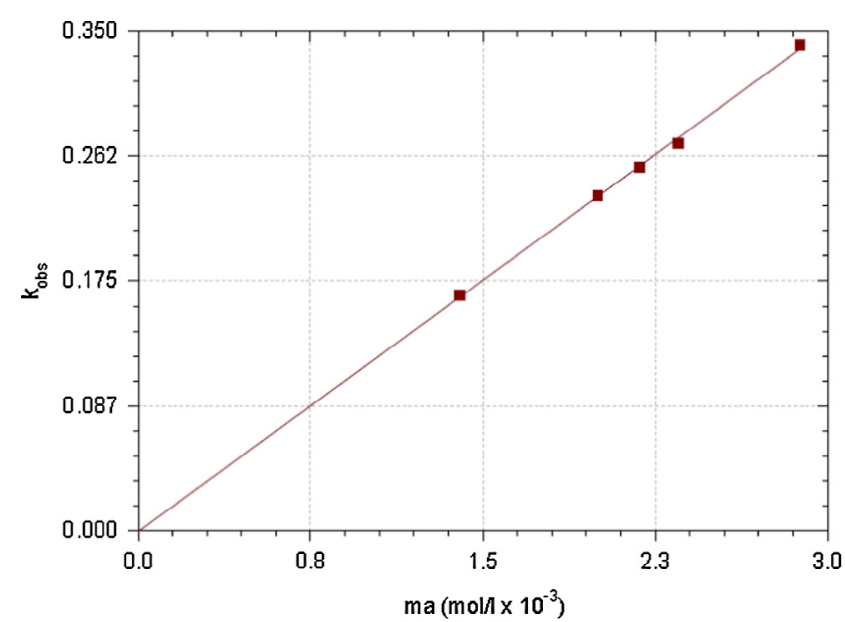

Fig. 6. Linear regression analysis of $k_{\mathrm{obs}}\left(\mathrm{s}^{-1}\right) v \mathrm{~s}$. [ma] $\left(\lambda=416 \mathrm{~nm}, T=298\right.$ in $\mathrm{CHCl}_{3}$; reaction: $\mathbf{6 d}+\mathrm{ma} \rightarrow \mathbf{6 a}+\mathrm{nq})$.

\section{Conclusion}

We have synthesized and characterized some novel palladium (0) olefin complexes bearing two NHC as spectator ligands. We have also prepared mixed heteroleptic olefin derivatives bearing $\mathrm{NHC}$ and $\mathrm{PPh}_{3}$, PTA or DIC co-ligands. We have studied the olefin exchange between the coordinated napthoquinone of complex $\mathbf{6 d}$ and maleic anhydride to give $\mathbf{6 a}$. The second-order rate constant was determined by linear regression of the pseudo-first order rate constants measured by UV-Vis spectrophotometry carried out in $\mathrm{CHCl}_{3}$ at $298 \mathrm{~K}$. Such an experimental technique is unusual when the very fast olefin exchange reactions in $\operatorname{Pd}(0)$ complexes are studied. In the present case, however, thanks to the steric retard induced by the bulky substituents it was possible to follow the reaction progress. At the best of our knowledge this adds a further item to the few available [11a,21]. Finally, we have carried out the SC-XRD of the complexes $\mathbf{6 d}$ and $\mathbf{8 b}$.

\section{Experimental}

\subsection{Solvents and reagents}

The solvents $\mathrm{CH}_{2} \mathrm{Cl}_{2}$ and $\mathrm{CH}_{3} \mathrm{CN}$ were distilled over $\mathrm{CaH}_{2}$, acetone was refluxed over $\mathbf{4 a}$ molecular sieves and distilled. All other solvents and chemicals were commercial grade products and used as purchased. 
4.2. IR, NMR, UV-Vis measurements and elemental analysis

The IR, ${ }^{1} \mathrm{H},{ }^{13} \mathrm{C}$ and ${ }^{31} \mathrm{P}$ NMR spectra were recorded on a PerkinElmer Spectrum One spectrophotometer and on a Bruker 300 Avance spectrometer, respectively. The UV-Vis spectra were recorded on a 1-40 PE spectrofotometer equipped with a Peltier thermostat apparatus.

The elemental analysis of the synthesized complexes was carried out using an Elementar CHN "CUBO micro Vario" analyzer.

\subsection{Kinetic measurements}

The reaction between complex $\mathbf{6 d}$ and maleic anhydride was at first studied by ${ }^{1} \mathrm{H}$ NMR by dissolving the complex under study in $0.6 \mathrm{ml}$ of $\mathrm{CDCl}_{3}\left([\text { Complex }]_{0} \approx 1.2 \times 10^{-2} \mathrm{~mol} \mathrm{dm}^{-3}\right)$, adding a microaliquot of a concentrated $\mathrm{CDCl}_{3}$ solution of maleic anhydride ([ma] $\approx 1.1 \times 10^{-1} \mathrm{~mol} \mathrm{dm}^{-3}$ ) and monitoring the signal for the disappearance of the starting complex. The reaction was then studied by UV-Vis spectrophotometry by mixing freshly prepared $\mathrm{CHCl}_{3}$ solutions of complex $\mathbf{6 d}\left([\mathbf{6 d}]=8 \times 10^{-5} \mathrm{~mol} \mathrm{dm}^{-3}\right)$ and microaliquots of concentrated solution of maleic anhydride ([ma] = at least $8 \times 10^{-4} \mathrm{~mol} \mathrm{dm}^{-3}$ ) and recording the absorbance changes as a function of time in the $280-560$ wavelength interval and at an optimized wavelength.

\subsection{Data analysis}

Non linear regression analysis of the data related to kinetics measurements was performed by locally adapted routines written in the ORIGIN ${ }^{\circledR} 7.5$ environment.

\subsection{Computational details}

Theoretical calculations were performed with the gaussian 09 [20] package using the functional hybrid meta-GGA M06 [22] and the Def2-TZVP basis set [23]. Geometry optimization was performed without any symmetry constraint, followed by analytical frequency calculation to confirm that a minimum had been reached. Solvent effects $\left(\mathrm{CH}_{2} \mathrm{Cl}_{2}, \varepsilon=9.93\right)$ were included using CPCM [24].

\subsection{Crystal structure determinations}

The crystal data of compounds $\mathbf{6 d}$ and $\mathbf{8 b}$ were collected at room temperature using a Nonius Kappa CCD diffractometer with graphite monochromated Mo $\mathrm{K} \alpha$ radiation. The data sets were integrated with the Denzo-SMN package [25] and corrected for Lorentz, polarization and absorption effects (SORTAV) [26]. The structures were solved by direct methods using SIR97 [27] system of programs and refined using full-matrix least-squares with all non-hydrogen atoms anisotropically and hydrogens included on calculated positions, riding on their carrier atoms.

All calculations were performed using SHELXL-2014/6 [28] and PARST [29] implemented in WINGX [30] system of programs. A selection of bond distances and angles is given in Table SM1 and the crystal data are given in Table SM2 (Supplementary Material).

\subsection{Syntesis of the precursors}

\subsubsection{Synthesis of the 1,3-bis(4-methylbenzyl)-2,3-dihydro-1H-imidazole bromide ligand}

$3.647 \mathrm{~g}(0.021 \mathrm{~mol})$ of 1-(4-methylbenzyl)-1H-imidazole were dissolved in $50 \mathrm{ml}$ of anhydrous acetonitrile under inert atmosphere (Ar) in a two necked flask. $3.5 \mathrm{~g}(0.034 \mathrm{~mol})$ of $\mathrm{NaBr}$ and $3 \mathrm{ml}(0.023 \mathrm{~mol})$ of 1-chloromethyl-4-methylbenzene were successively added to the solution and the resulting mixture was stirred under reflux for $36 \mathrm{~h}$. The unreacted salts were filtered off on a gooch and repeatedly washed with $\mathrm{CH}_{2} \mathrm{Cl}_{2}$ and the clear solution evaporated under vacuum to small volume. The addition of diethylether to the concentrated solution induces the precipitation of the title product which was repeatedly washed with diethylether and dried under vacuum. $6.62 \mathrm{~g}$ (yield $88 \%$ ) of the imidazolium salt as a white microcrystalline powder were obtained.

${ }^{1} \mathrm{H} \mathrm{NMR}\left(\mathrm{CDCl}_{3}, T=298 \mathrm{~K}, \mathrm{ppm}\right) \delta: 2.33\left(\mathrm{~s}, 6 \mathrm{H}\right.$, tol- $\left.\mathrm{CH}_{3}\right), 5.50(\mathrm{~s}$, $\left.4 \mathrm{H}, \mathrm{N}-\mathrm{CH}_{2}\right), 7.15(\mathrm{~d}, \mathrm{~J}=1.6 \mathrm{~Hz}, 2 \mathrm{H}, \mathrm{CH}=\mathrm{CH} \mathrm{Im}), 7,17-7.20(\mathrm{~m}, 4 \mathrm{H}$, $\mathrm{Ph}), 7,33-7.36$ ( $\mathrm{m}, 4 \mathrm{H}, \mathrm{Ph}), 10.98$ (bt, 1H, NCHN).

${ }^{13} \mathrm{C}\left\{{ }^{1} \mathrm{H}\right\} N M R\left(\mathrm{CDCl}_{3}, T=298 \mathrm{~K}, \mathrm{ppm}\right) \delta: 21.1\left(\mathrm{CH}_{3}, \mathrm{Ph}-\mathrm{CH}_{3}\right), 53.3$ $\left(\mathrm{CH}_{2}, \mathrm{NCH}_{2}\right), 121.4(\mathrm{CH}, \mathrm{CH}=\mathrm{CH} \mathrm{Im}), 129.0(\mathrm{CH}, \mathrm{Ph}$ o-C $), 129.5(\mathrm{C}$, Ph $i-\mathrm{C}), 130.0$ (CH, Ph m-C), 139.6 (C, Ph $p-C), 137.2(\mathrm{CH}, \mathrm{NCHN})$.

IR $(\mathrm{KBr}): v_{\mathrm{C}=\mathrm{N}}=1557 \mathrm{~cm}^{-1}$.

Anal. Calc. for $\mathrm{C}_{19} \mathrm{H}_{21} \mathrm{BrN}_{2}$ : C, 63.87; H, 5.92; N, 7.84. Found: C, $63.73 ; \mathrm{H}, 5.81 ; \mathrm{N}, 7.99$.

\subsubsection{Synthesis of the silver complex 2}

To $0.4 \mathrm{~g}\left(1.12 \times 10^{-3} \mathrm{~mol}\right)$ of 1,3-bis(4-methylbenzyl)-2,3-dihydro- $1 \mathrm{H}$-imidazole bromide, dissolved in $30 \mathrm{ml}$ of anhydrous $\mathrm{CH}_{2} \mathrm{Cl}_{2}, 0.156 \mathrm{~g}\left(6.72 \times 10^{-4} \mathrm{~mol}\right)$ of $\mathrm{Ag}_{2} \mathrm{O}$ was added under inert atmosphere $(\mathrm{Ar})$. The resulting mixture was stirred in the dark for $24 \mathrm{~h}$, filtered by means of a millipore apparatus and eventually reduced under vacuum to small volume. Slow addition of diethylether induces the precipitation of a white solid which was repeatedly washed with diethylether and pentane and dried under vacuum. $0.489 \mathrm{~g}$ ( $94 \%$ yield) of the title complex was obtained.

${ }^{1} \mathrm{H} \mathrm{NMR}\left(\mathrm{CDCl}_{3}, T=298 \mathrm{~K}, \mathrm{ppm}\right) \delta: 2.35\left(\mathrm{~s}, 6 \mathrm{H}\right.$, tol- $\left.\mathrm{CH}_{3}\right), 5.25(\mathrm{~s}$, $\left.4 \mathrm{H}, \mathrm{N}-\mathrm{CH}_{2}\right), 6.90(\mathrm{~s}, 2 \mathrm{H}, \mathrm{CH}=\mathrm{CH} \mathrm{Im}), 7,16-7.17(\mathrm{~m}, 8 \mathrm{H}$, tol-H).

${ }^{13} \mathrm{C}\left\{{ }^{1} \mathrm{H}\right\}$ NMR $\left(\mathrm{CDCl}_{3}, T=298 \mathrm{~K}, \mathrm{ppm}\right) \delta: 21.1\left(\mathrm{CH}_{3}, \mathrm{Ph}-\mathrm{CH}_{3}\right), 55.5$ $\left(\mathrm{CH}_{2}, \mathrm{NCH}_{2}\right), 121.2(\mathrm{CH}, \mathrm{CH}=\mathrm{CH} \mathrm{Im}), 127.8(\mathrm{CH}$, tol o-C $), 129.7(\mathrm{CH}$, tol $m-\mathrm{C}$ ), 132.3 (C, tol $i-\mathrm{C}$ ), 138.5 (C, tol $p-\mathrm{C}$ ), 180.8 (C, NCN).

Anal. Calc. for $\mathrm{C}_{19} \mathrm{H}_{20} \mathrm{AgBrN}_{2}$ : C, 49.17; H, 4.34; N, 6.04. Found: C, 49.22; H, 4.47; N, 5.96.

\subsection{Synthesis of bis-NHC complexes}

\subsubsection{Synthesis of complex $\mathbf{5 b}$}

To $0.0724 \mathrm{~g}\left(1.808 \times 10^{-4} \mathrm{~mol}\right)$ of complex $\mathbf{1 b}$ dissolved in 10 $\mathrm{ml}$ of anhydrous $\mathrm{CH}_{2} \mathrm{Cl}_{2}, 0.1678 \mathrm{~g}\left(3.616 \times 10^{-4} \mathrm{~mol}\right)$ of 2 dissolved in $5 \mathrm{ml}$ of anhydrous $\mathrm{CH}_{2} \mathrm{Cl}_{2}$ was added under inert atmosphere (Ar). The mixture was stirred for $15 \mathrm{~m}$ and then the $\mathrm{AgBr}$ was filtered off with a millipore apparatus. The clear solution was evaporated to dryness and the residue treated with diethylether The precipitate was filtered off on a gooch and washed several times with diethylether and pentane and dried under vacuum. $0.1108 \mathrm{~g}$ (83\% yield) of the title compound was obtained as a white powder.

${ }^{1} \mathrm{H}$ NMR $\left(\mathrm{CD}_{2} \mathrm{Cl}_{2}, T=298 \mathrm{~K}, \mathrm{ppm}\right) \delta: 2.32\left(\mathrm{~s}, 12 \mathrm{H}\right.$, tol- $\left.\mathrm{CH}_{3}\right), 2.33$ $\left(\mathrm{s}, 2 \mathrm{H}, \mathrm{CH}=\mathrm{CH}\right.$ ), 5.12, 5.30 (AB system, $\left.J=14.7 \mathrm{~Hz}, 8 \mathrm{H}, \mathrm{N}-\mathrm{CH}_{2}\right), 6.79$ (s, $4 \mathrm{H}, \mathrm{CH}=\mathrm{CH} \mathrm{Im}), 7.00-7.12\left(\mathrm{~m}, 16 \mathrm{H}\right.$, tol-H). ${ }^{13} \mathrm{C}\left\{{ }^{1} \mathrm{H}\right\}$ NMR $\left(\mathrm{CD}_{2} \mathrm{Cl}_{2}, T=298 \mathrm{~K}, \mathrm{ppm}\right) \delta: 13.9(\mathrm{CH}, \mathrm{CH}=\mathrm{CH}), 20.8\left(\mathrm{CH}_{3}\right.$, tol- $\left.\mathrm{CH}_{3}\right), 54.2\left(\mathrm{CH}_{2}, \mathrm{NCH}_{2}\right), 120.9(\mathrm{CH}, \mathrm{CH}=\mathrm{CH} \mathrm{Im}), 123.8(\mathrm{C}, \mathrm{CN})$, $127.6(\mathrm{CH}$, tol $o-\mathrm{C}), 129.3(\mathrm{CH}$, tol $m-\mathrm{C}), 133.8(\mathrm{C}$, tol $i-\mathrm{C}), 137.7$ (C, tol $p-\mathrm{C}), 190.3(\mathrm{C}, \mathrm{NCN})$.

IR $(\mathrm{KBr}): v_{\mathrm{CN}}=2190 \mathrm{~cm}^{-1}$.

Anal. Calc. for $\mathrm{C}_{42} \mathrm{H}_{42} \mathrm{~N}_{6} \mathrm{Pd}: \mathrm{C}, 68.42 ; \mathrm{H}, 5.74 ; \mathrm{N}, 11.40$. Found: $\mathrm{C}$, 68.57; H, 5.71; N, 11.27.

Derivatives $\mathbf{5 c}$ and $\mathbf{5 d}$ were prepared in a similar way using the appropriate reactants.

\subsubsection{Synthesis of complex $\mathbf{5 c}$}

Whitish microcrystals; Yield 94\%.

${ }^{1} \mathrm{H} \mathrm{NMR}\left(\mathrm{CDCl}_{3}, T=298 \mathrm{~K}, \mathrm{ppm}\right) \delta: 2.33\left(\mathrm{~s}, 3 \mathrm{H}\right.$, tolyl- $\left.\mathrm{CH}_{3}\right), 3.47$ $\left(\mathrm{s}, 12 \mathrm{H}, \mathrm{OCH}_{3}\right), 5.27\left(\mathrm{~s}, 4 \mathrm{H}, \mathrm{N}-\mathrm{CH}_{2}\right), 6.58(\mathrm{~s}, 2 \mathrm{H}, \mathrm{CH}=\mathrm{CH} \mathrm{Im})$, 6.87-6.90 (m, 2H, tolyl $m-\mathrm{H}), 7.06-7.09(\mathrm{~m}, 2 \mathrm{H}$, tolyl $o-\mathrm{H}) .{ }^{13} \mathrm{C}$ 
$\left\{{ }^{1} \mathrm{H}\right\}$ NMR $\left(\mathrm{CDCl}_{3}, T=298 \mathrm{~K}, \mathrm{ppm}\right) \delta: 21.5\left(\mathrm{CH}_{3}, \mathrm{Ph}-\mathrm{CH}_{3}\right), 51.9\left(\mathrm{CH}_{3}\right.$, $\left.\mathrm{OCH}_{3}\right), 54.2\left(\mathrm{CH}_{2}, \mathrm{NCH}_{2}\right), 120.9(\mathrm{CH}, \mathrm{CH}=\mathrm{CH} \mathrm{Im}), 128.2(\mathrm{CH}$, tolyl $o-\mathrm{C}), 129.6(\mathrm{CH}$, tolyl $m-\mathrm{C}), 134.3(\mathrm{C}$, tolyl $i-\mathrm{C}), 137.7$ (C, tolyl $p$ C), 172.1 (C,CO), 188.7 (C, NCN). IR ( $\mathrm{KBr}): v_{\mathrm{C}=\mathrm{O}}=1686,1706 \mathrm{~cm}^{-1}$. Anal. Calc. for $\mathrm{C}_{48} \mathrm{H}_{52} \mathrm{~N}_{4} \mathrm{O}_{8} \mathrm{Pd}$ : C, 62.71; H, 5.70; N, 6.09. Found: C, 62.57; H, 5.78; N, 5.96.

\subsubsection{Synthesis of complex $\mathbf{5 d}$}

Orange microcrystals; Yield 68\%.

${ }^{1} \mathrm{H}$ NMR $\left(\mathrm{CD}_{2} \mathrm{Cl}_{2}, T=298 \mathrm{~K}, \mathrm{ppm}\right) \delta: 2.34\left(\mathrm{~s}, 12 \mathrm{H}\right.$, tol- $\left.\mathrm{CH}_{3}\right), 4.66$ $(\mathrm{s}, 2 \mathrm{H}, \mathrm{CH}=\mathrm{CH}), 5.00,4.96$ (AB system, $\left.J=14.8 \mathrm{~Hz}, 8 \mathrm{H}, \mathrm{N}-\mathrm{CH}_{2}\right), 6.64$ (s, $4 \mathrm{H}, \mathrm{CH}=\mathrm{CH}$ Im), 6.88-7.11 (m, 16H, tol-H), 7.37-7.40 (m, $2 \mathrm{H}$, nq-H), 7.94-7.97 (m, 2H, nq-H), ${ }^{13} \mathrm{C}\left\{{ }^{1} \mathrm{H}\right\}$ NMR $\left(\mathrm{CD}_{2} \mathrm{Cl}_{2}, T=298 \mathrm{~K}\right.$, ppm) $\delta: 20.8\left(\mathrm{CH}_{3}\right.$, tol- $\left.\mathrm{CH}_{3}\right), 54.4\left(\mathrm{CH}_{2}, \mathrm{NCH}_{2}\right), 60.4(\mathrm{CH}, \mathrm{CH}=$ $\mathrm{CH}), 120.9(\mathrm{CH}, \mathrm{CH}=\mathrm{CH} \mathrm{Im}), 124.6(\mathrm{CH}, \mathrm{nq}-\mathrm{CH}), 127.7(\mathrm{CH}$, tol oC), $129.2(\mathrm{CH}$, tol $m-\mathrm{C}), 129.5(\mathrm{CH}, \mathrm{nq}-\mathrm{CH}), 129.9(\mathrm{C}, \mathrm{nq}-\mathrm{CH})$, $133.4(\mathrm{C}$, tol $i-\mathrm{C}), 137.6(\mathrm{C}$, tol $p-\mathrm{C}), 137.7(\mathrm{C}$, nq-CH), $181.8(\mathrm{C}$, $\mathrm{CO}), 188.8(\mathrm{C}, \mathrm{NCN})$.

IR $(\mathrm{KBr}): v_{\mathrm{C}=\mathrm{O}}=1619 \mathrm{~cm}^{-1}$.

Anal. Calc. for $\mathrm{C}_{48} \mathrm{H}_{46} \mathrm{~N}_{4} \mathrm{O}_{2} \mathrm{Pd}$ : C, 70.54; $\mathrm{H}, 5.67 ; \mathrm{N}, 6.85$. Found: C, $70.41 ; \mathrm{H}, 5.73 ; \mathrm{N}, 6.89$.

\subsection{Mixed triphenyl phosphine-NHC complexes}

\subsubsection{Synthesis of complex $\mathbf{6 a}$}

To $0.080 \mathrm{~g}\left(1.906 \times 10^{-4} \mathrm{~mol}\right)$ of complex 1a dissolved in $10 \mathrm{ml}$ of anhydrous $\mathrm{CH}_{2} \mathrm{Cl}_{2}, 0.0885 \mathrm{~g}\left(1.906 \times 10^{-4} \mathrm{~mol}\right)$ of 2 and $0.050 \mathrm{~g}$ $\left(1.906 \times 10^{-4}\right)$ of $\mathrm{PPh}_{3}$ dissolved together in $5 \mathrm{ml}$ of anhydrous $\mathrm{CH}_{2} \mathrm{Cl}_{2}$ were added under inert atmosphere (Ar). The mixture was stirred for $15 \mathrm{~m}$ and then $\mathrm{AgBr}$ was filtered off with a millipore apparatus. The clear solution was evaporated to small volume under vacuum and treated with diethylether. The pale yellow precipitate was filtered off in a gooch and washed with diethylether and pentane and dried under vacuum. $0.1217 \mathrm{~g}$ ( $86 \%$ yield) of the title compound was obtained.

${ }^{1} \mathrm{H}$ NMR $\left(\mathrm{CDCl}_{3}, T=298 \mathrm{~K}, \mathrm{ppm}\right) \delta: 2.27\left(\mathrm{~s}, 6 \mathrm{H}\right.$, tol- $\left.\mathrm{CH}_{3}\right), 3.80$ $\left(\mathrm{dd}, J_{\mathrm{HH}}=3.9 \mathrm{~Hz}, J_{\mathrm{HP}}=2.8 \mathrm{~Hz}, 1 \mathrm{H}, \mathrm{CH}=\mathrm{CH}\right.$ trans $\left.-\mathrm{C}\right), 4.03\left(\mathrm{dd}, J_{\mathrm{HP}}=\right.$ $10.3 \mathrm{~Hz}, J_{\mathrm{HH}}=3.9 \mathrm{~Hz}, 1 \mathrm{H}, \mathrm{CH}=\mathrm{CH}$ trans $-\mathrm{P}$ ), 4.50 (bs, $2 \mathrm{H}, \mathrm{N}-\mathrm{CH}_{2}$ ), 4.88 (bd, $\left.2 \mathrm{H}, \mathrm{N}-\mathrm{CH}_{2}\right), 6.68(\mathrm{~s}, 2 \mathrm{H}, \mathrm{CH}=\mathrm{CH} \mathrm{Im}), 6.89-6.94(\mathrm{bm}$, $8 \mathrm{H}$, tol-H), 7.11-7.42 (m, 15H, $\left.\mathrm{PPh}_{3}\right)$.

${ }^{1} \mathrm{H}$ NMR $\left(\mathrm{CD}_{2} \mathrm{Cl}_{2}, T=213 \mathrm{~K}, \mathrm{ppm}\right) \delta: 2.17\left(\mathrm{~s}, 3 \mathrm{H}\right.$, tol- $\left.\mathrm{CH}_{3}\right), 2.44(\mathrm{~s}$, $3 \mathrm{H}$, tol- $\left.\mathrm{CH}_{3}\right), 3.88$ (dd, $J_{\mathrm{HH}}=3.9 \mathrm{~Hz}, J_{\mathrm{HP}}=2.8 \mathrm{~Hz}, 1 \mathrm{H}, \mathrm{CH}=\mathrm{CH}$ transC), $4.03\left(\mathrm{dd}, J_{\mathrm{HP}}=10.3 \mathrm{~Hz}, J_{\mathrm{HH}}=3.9 \mathrm{~Hz}, 1 \mathrm{H}, \mathrm{CH}=\mathrm{CH}\right.$ trans-P $), 4.04$ (d, $\left.J=14.4 \mathrm{~Hz}, 1 \mathrm{H}, \mathrm{N}-\mathrm{CH}_{2}\right), 4.53\left(\mathrm{~d}, J=14.2 \mathrm{~Hz}, 1 \mathrm{H}, \mathrm{N}-\mathrm{CH}_{2}\right), 4.70$ (d, $\left.J=14.4 \mathrm{~Hz}, 1 \mathrm{H}, \mathrm{N}-\mathrm{CH}_{2}\right), 4.86\left(\mathrm{~d}, J=14.2 \mathrm{~Hz}, 1 \mathrm{H}, \mathrm{N}-\mathrm{CH}_{2}\right), 6.70$ $(\mathrm{d}, J=1.7 \mathrm{~Hz}, 1 \mathrm{H}, \mathrm{CH}=\mathrm{CH} \mathrm{Im}), 6.74(\mathrm{~d}, J=1.7 \mathrm{~Hz}, 1 \mathrm{H}, \mathrm{CH}=\mathrm{CH}$ Im), 6.76-6.86 (m, 4H, tol-H), 6.97-7.45 ( $\mathrm{m}, 19 \mathrm{H}$, tol-H $\left.\mathrm{PPh}_{3}\right)$.

${ }^{13} \mathrm{C}\left\{{ }^{1} \mathrm{H}\right\}$ NMR $\left(\mathrm{CD}_{2} \mathrm{Cl}_{2}, T=298 \mathrm{~K}, \mathrm{ppm}\right) \delta: 20.7\left(\mathrm{CH}_{3}\right.$, tol- $\left.\mathrm{CH}_{3}\right)$, $45.2(\mathrm{CH}, \mathrm{CH}=\mathrm{CH}$ trans $-\mathrm{C}), 47.0\left(\mathrm{~d}, \mathrm{CH}, J_{\mathrm{CP}}=30.0 \mathrm{~Hz}, \mathrm{CH}=\mathrm{CH}\right.$ trans-P), $54.3\left(\mathrm{CH}_{2}, \mathrm{NCH}_{2}\right), 121.0(\mathrm{CH}, \mathrm{CH}=\mathrm{CH} \mathrm{Im}), 128.4(\mathrm{CH}$, tol $o-\mathrm{C}), 129.7$ ( $\mathrm{CH}$, tol $m-\mathrm{C}), 133.5$ (C, tol $i-\mathrm{C}), 172.5$ (C, CO trans-C), 172.6 (C, d, $J_{\mathrm{CP}}=5.4$. Hz, CO trans-P), $188.2\left(\mathrm{C}, \mathrm{d}, J_{\mathrm{CP}}=14.4 \mathrm{~Hz}\right.$, NCN $).{ }^{31} \mathrm{P}\left\{{ }^{1} \mathrm{H}\right\}$ NMR $\left(\mathrm{CDCl}_{3}, T=298 \mathrm{~K}, \mathrm{ppm}\right) \delta: 29.9$.

IR $(\mathrm{KBr}): v_{\mathrm{C}=\mathrm{O}}=1717,1784 \mathrm{~cm}^{-1}$.

Anal. Calc. for $\mathrm{C}_{41} \mathrm{H}_{37} \mathrm{~N}_{2} \mathrm{O}_{3} \mathrm{PPd}$ : C, 66.18; H, 5.15; N, 3.76. Found: C, 66.03; H, 5.22; N, 3.65.

Derivatives $\mathbf{6 b}-\mathbf{d}$, were prepared in a similar way using the appropriate reactants.

\subsubsection{Synthesis of complex $\mathbf{6 b}$}

Yellow microcrystals; Yield $83 \%$.

${ }^{1} \mathrm{H}$ NMR $\left(\mathrm{CD}_{2} \mathrm{Cl}_{2}, T=298 \mathrm{~K}, \mathrm{ppm}\right) \delta: 2.29\left(\mathrm{~s}, 6 \mathrm{H}\right.$, tol- $\left.\mathrm{CH}_{3}\right), 2.66-$ $2.76(\mathrm{~m}, 4.25,2 \mathrm{H}, \mathrm{CH}=\mathrm{CH}$, trans $-\mathrm{C}$ and trans $-\mathrm{P}), 4.84$ (bs, $4 \mathrm{H}$, $\left.\mathrm{N}-\mathrm{CH}_{2}\right), 6.78(\mathrm{~s}, 2 \mathrm{H}, \mathrm{CH}=\mathrm{CH} \mathrm{Im}), 6.97-7.03(\mathrm{~m}, 8 \mathrm{H}$, tol-H $)$, 7.21-7.46 (m, 15H, $\left.\mathrm{PPh}_{3}\right)$.
${ }^{1} \mathrm{H}$ NMR $\left(\mathrm{CD}_{2} \mathrm{Cl}_{2}, T=213 \mathrm{~K}, \mathrm{ppm}\right) \delta: 2.17\left(\mathrm{~s}, 3 \mathrm{H}\right.$, tol- $\left.-\mathrm{CH}_{3}\right), 2.27(\mathrm{~s}$, $3 \mathrm{H}$, tol- $\mathrm{CH}_{3}$ ), ), 2.79 (ABX system $(\mathrm{A}), J_{\mathrm{HP}}=12.7 \mathrm{~Hz}, J_{\mathrm{HH}}=12.5 \mathrm{~Hz}$ $1 \mathrm{H}, \mathrm{CH}=\mathrm{CH}$ trans $-\mathrm{P}$ ), $2.87\left(\mathrm{ABX}\right.$ system $(\mathrm{B}), J_{\mathrm{HH}}=12.7 \mathrm{~Hz}, J_{\mathrm{HP}}=$ $2.7 \mathrm{~Hz}, 1 \mathrm{H}, \mathrm{CH}=\mathrm{CH}$ trans-C), $4.34\left(\mathrm{~d}, J=14.4 \mathrm{~Hz}, 1 \mathrm{H}, \mathrm{N}-\mathrm{CH}_{2}\right), 4.48$ $\left(\mathrm{d}, J=14.1 \mathrm{~Hz}, 1 \mathrm{H}, \mathrm{N}-\mathrm{CH}_{2}\right), 4.91\left(\mathrm{~d}, J=14.4 \mathrm{~Hz}, 1 \mathrm{H}, \mathrm{N}-\mathrm{CH}_{2}\right), 4.93$ (d, $\left.J=14.1 \mathrm{~Hz}, 1 \mathrm{H}, \mathrm{N}-\mathrm{CH}_{2}\right), 6.71(\mathrm{~d}, J=1.6 \mathrm{~Hz}, 1 \mathrm{H}, \mathrm{CH}=\mathrm{CH} \mathrm{Im})$, $6.74(\mathrm{~d}, J=1.6 \mathrm{~Hz}, 1 \mathrm{H}, \mathrm{CH}=\mathrm{CH} \mathrm{Im}), 6.79(\mathrm{~d}, J=7.8 \mathrm{~Hz}, 2 \mathrm{H}$, tol-H), $6.95(\mathrm{~d}, J=7.8 \mathrm{~Hz}, 2 \mathrm{H}$, tol-H), 6.94-7.02 (b AB system, $4 \mathrm{H}$, tol-H), 7.07-7.46 (m, 15H, $\left.\mathrm{PPh}_{3}\right)$.

${ }^{13} \mathrm{C}\left\{{ }^{1} \mathrm{H}\right\}$ NMR $\left(\mathrm{CD}_{2} \mathrm{Cl}_{2}, T=298 \mathrm{~K}, \mathrm{ppm}\right) \delta: 20.8\left(\mathrm{CH}_{3}\right.$, tol- $\left.\mathrm{CH}_{3}\right)$, $21.3\left(\mathrm{~d}, \mathrm{CH}, J_{\mathrm{CP}}=3.0 \mathrm{~Hz}, \mathrm{CH}=\mathrm{CH}\right.$ trans $\left.-\mathrm{C}\right), 22.3\left(\mathrm{~d}, \mathrm{CH}, J_{\mathrm{CP}}=40.7\right.$ $\mathrm{Hz}, \mathrm{CH}=\mathrm{CH}$ trans-P), $54.3\left(\mathrm{CH}_{2}, \mathrm{NCH}_{2}\right), 120.9(\mathrm{CH}, \mathrm{CH}=\mathrm{CH} \mathrm{Im})$, 123.7 (C, CN trans-C), 123.7 (d, C, $J_{\mathrm{CP}}=7.6 \mathrm{~Hz}, \mathrm{CN}$ trans-P), 128.4 (CH, tol o-C), $129.3(\mathrm{CH}$, tol $m-\mathrm{C}), 133.1(\mathrm{C}$, tol $i-\mathrm{C}), 137.9(\mathrm{C}$, tol $p-\mathrm{C}), 188.5$ (C, d, $\left.J_{\mathrm{CP}}=12.0 \mathrm{~Hz}, \mathrm{NCN}\right) .{ }^{31} \mathrm{P}\left\{{ }^{1} \mathrm{H}\right\} \mathrm{NMR}\left(\mathrm{CD}_{2} \mathrm{Cl}_{2}, T=\right.$ $298 \mathrm{~K}, \mathrm{ppm}) \delta: 27.5$.

IR (KBr): $v_{\mathrm{CN}}=2196 \mathrm{~cm}^{-1}$.

Anal. Calc. for $\mathrm{C}_{41} \mathrm{H}_{37} \mathrm{~N}_{4} \mathrm{PPd}$ : C, 68.00; H, 5.29; N, 7.74. Found: C, 68.12; H, 5.33; N, 7.65.

\subsubsection{Synthesis of complex $\mathbf{6 c}$}

White microcrystals; Yield $98 \%$.

${ }^{1} \mathrm{H}$ NMR $\left(\mathrm{CDCl}_{3}, T=298 \mathrm{~K}, \mathrm{ppm}\right) \delta: 2.26\left(\mathrm{~s}, 6 \mathrm{H}\right.$, tol $\left.-\mathrm{CH}_{3}\right), 3.30(\mathrm{~s}$, $\left.6 \mathrm{H}, \mathrm{OCH}_{3}\right), 3.55\left(\mathrm{~s}, 6 \mathrm{H}, \mathrm{OCH}_{3}\right), 4.63\left(\mathrm{~d}, J=14.4 \mathrm{~Hz}, 2 \mathrm{H}, \mathrm{N}-\mathrm{CH}_{2}\right), 5.19$ (d, $\left.J=14.4 \mathrm{~Hz}, 2 \mathrm{H}, \mathrm{N}-\mathrm{CH}_{2}\right), 6.57(\mathrm{~s}, 2 \mathrm{H}, \mathrm{CH}=\mathrm{CH} \mathrm{Im}), 6.88-6.95(\mathrm{~m}$, $8 \mathrm{H}$, tol $m-\mathrm{H}$, tol $o-\mathrm{H}), 7.13-7.38\left(\mathrm{~m}, 15 \mathrm{H}, \mathrm{PPh}_{3}\right)$.

${ }^{13} \mathrm{C}\left\{{ }^{1} \mathrm{H}\right\}$ NMR $\left(\mathrm{CDCl}_{3}, T=298 \mathrm{~K}, \mathrm{ppm}\right) \delta: 21.5\left(\mathrm{CH}_{3}, \mathrm{Ph}-\mathrm{CH}_{3}\right), 51.7$ $\left(\mathrm{CH}_{3}, \mathrm{OCH}_{3}\right), 52.2\left(\mathrm{CH}_{3}, \mathrm{OCH}_{3}\right), 54.4\left(\mathrm{CH}_{2}, \mathrm{NCH}_{2}\right), 120.7(\mathrm{CH}, \mathrm{CH}=$ $\mathrm{CH} \mathrm{Im}), 129.3(\mathrm{CH}$, tol $o-\mathrm{C}), 129.6(\mathrm{CH}$, tol $m-\mathrm{C}), 133.5(\mathrm{C}$, tol $i-\mathrm{C})$, 137.9 (C, tol p-C), 170.9 (C,CO), 171.2 (C, d, J $\left.J_{C P}=4.3 \mathrm{~Hz}, \mathrm{CO}\right)$, $187.5\left(\mathrm{C}, \mathrm{d}, J_{\mathrm{CP}}=17.7 \mathrm{~Hz}, \mathrm{NCN}\right)$.

${ }^{31} \mathrm{P}\left\{{ }^{1} \mathrm{H}\right\}$ NMR $\left(\mathrm{CDCl}_{3}, T=298 \mathrm{~K}, \mathrm{ppm}\right) \delta: 29.9$.

IR $(\mathrm{KBr}): v_{\mathrm{C}=\mathrm{O}}=1713,1681 \mathrm{~cm}^{-1}$.

Anal. Calc. for $\mathrm{C}_{47} \mathrm{H}_{47} \mathrm{~N}_{2} \mathrm{O}_{8} \mathrm{PPd}$ : C, 62.29; $\mathrm{H}, 5.34 ; \mathrm{N}, 3.09$. Found: C, 62.38; H, 5.44; N, 2.99 .

\subsubsection{Synthesis of complex $\mathbf{6 d}$}

Yellow microcrystals; Yield $86 \%$.

${ }^{1} \mathrm{H}$ NMR $\left(\mathrm{CD}_{2} \mathrm{Cl}_{2}, T=298 \mathrm{~K}, \mathrm{ppm}\right) \delta: 2.27\left(\mathrm{~s}, 3 \mathrm{H}\right.$, tol- $\left.-\mathrm{CH}_{3}\right), 2.34(\mathrm{~s}$, $3 \mathrm{H}$, tol- $\left.\mathrm{CH}_{3}\right), 4.25$ (d, $\left.J=14.6 \mathrm{~Hz}, 1 \mathrm{H}, \mathrm{N}-\mathrm{CH}_{2}\right), 4.43(\mathrm{~d}, J=14.6 \mathrm{~Hz}$, $\left.1 \mathrm{H}, \mathrm{N}-\mathrm{CH}_{2}\right), 4.61\left(\mathrm{dd}, J_{\mathrm{HH}}=7.3 \mathrm{~Hz}, 1 \mathrm{H}, \mathrm{CH}=\mathrm{CH}\right.$ trans $\left.-\mathrm{C}\right), 4.65(\mathrm{~d}, \mathrm{~J}$ $\left.=14.5 \mathrm{~Hz}, 1 \mathrm{H}, \mathrm{N}-\mathrm{CH}_{2}\right), 4.83\left(\mathrm{dd}, J_{\mathrm{HP}}=9.8 \mathrm{~Hz}, J_{\mathrm{HH}}=7.3 \mathrm{~Hz}, 1 \mathrm{H}, \mathrm{CH}\right.$ $=\mathrm{CH}$ trans $-\mathrm{P}), 5.13\left(\mathrm{~d}, J=14.5 \mathrm{~Hz}, 1 \mathrm{H}, \mathrm{N}-\mathrm{CH}_{2}\right), 6.54(\mathrm{~d}, J=7.9 \mathrm{~Hz}$, $2 \mathrm{H}$, tol-H), 6.59 (d, $J=1.8 \mathrm{~Hz}, 1 \mathrm{H}, \mathrm{CH}=\mathrm{CH} \mathrm{Im}), 6.73(\mathrm{~d}, J=1.8 \mathrm{~Hz}$, $1 \mathrm{H}, \mathrm{CH}=\mathrm{CH} \mathrm{Im}), 6.90(\mathrm{~d}, J=7.9 \mathrm{~Hz}, 2 \mathrm{H}$, tol-H), 6.89-7.56 (m, $21 \mathrm{H}, \mathrm{nq}-\mathrm{H}$, tol-H, $\left.\mathrm{PPh}_{3}\right), 7.90-7.97(\mathrm{~m}, 2 \mathrm{H}, \mathrm{nq}-\mathrm{H})$.

${ }^{13} \mathrm{C}\left\{{ }^{1} \mathrm{H}\right\}$ NMR $\left(\mathrm{CD}_{2} \mathrm{Cl}_{2}, T=298 \mathrm{~K}, \mathrm{ppm}\right) \delta: 20.7\left(\mathrm{CH}_{3}\right.$, tol- $\left.\mathrm{CH}_{3}\right)$, $20.8\left(\mathrm{CH}_{3}\right.$, tol- $\left.\mathrm{CH}_{3}\right), 63.6(\mathrm{CH}, \mathrm{CH}=\mathrm{CH}$ trans $-\mathrm{C}), 65.6\left(\mathrm{~d}, \mathrm{CH}, J_{\mathrm{CP}}=\right.$ $19.0 \mathrm{~Hz}, \mathrm{CH}=\mathrm{CH}$ trans $-\mathrm{P}), 54.0\left(\mathrm{CH}_{2}, \mathrm{NCH}_{2}\right), 54.4\left(\mathrm{CH}_{2}, \mathrm{NCH}_{2}\right)$, $120.9(\mathrm{CH}, \mathrm{CH}=\mathrm{CH} \mathrm{Im}), 125.0(\mathrm{CH}, \mathrm{nq}-\mathrm{CH}), 125.6(\mathrm{CH}, \mathrm{nq}-\mathrm{CH})$ $128.0(\mathrm{CH}$, tol $o-\mathrm{C}), 128.1(\mathrm{CH}$, tol $o-\mathrm{C}), 129.1(\mathrm{CH}$, tol $m-\mathrm{C}), 129.3$ $(\mathrm{CH}$, tol $m-\mathrm{C}), 130.6(\mathrm{CH}, \mathrm{nq}-\mathrm{CH}), 130.7(\mathrm{CH}, \mathrm{nq}-\mathrm{CH}), 132.7(\mathrm{C}$, tol $i-\mathrm{C}), 133.3(\mathrm{C}$, tol $i-\mathrm{C}), 136.8(\mathrm{C}, \mathrm{nq}-\mathrm{CH}), 137.0(\mathrm{C}, \mathrm{nq}-\mathrm{CH}), 137.6$ (C, tol p-C), $138.0(\mathrm{C}$, tol $p-\mathrm{C}), 183.3\left(\mathrm{C}, \mathrm{d}, J_{\mathrm{CP}}=7.1 \mathrm{~Hz}, \mathrm{CO}\right.$ transP), 183.4 (C,CO trans-C), 189.0 (C, d, J $\left.J_{\text {CP }}=21 \mathrm{~Hz}, \mathrm{NCN}\right) .{ }^{31} \mathrm{P}\left\{{ }^{1} \mathrm{H}\right\}$ NMR $\left(\mathrm{CDCl}_{3}, T=298 \mathrm{~K}, \mathrm{ppm}\right) \delta: 32.0$.

IR $(\mathrm{KBr}): v_{\mathrm{C}=\mathrm{O}}=1619 \mathrm{~cm}^{-1}$.

Anal. Calc. for $\mathrm{C}_{47} \mathrm{H}_{41} \mathrm{~N}_{2} \mathrm{O}_{2}$ PPd: C, 70.19; $\mathrm{H}, 5.26 ; \mathrm{N}, 3.48$. Found: C, $70.21 ; \mathrm{H}, 5.24 ; \mathrm{N}, 3.41$.

\subsubsection{Synthesis of complex $\mathbf{6 e}$}

To $0.080 \mathrm{~g}\left(1.819 \times 10^{-4} \mathrm{~mol}\right)$ of complex 1 e dissolved in $10 \mathrm{ml}$ of anhydrous $\mathrm{CH}_{2} \mathrm{Cl}_{2}, 0.0844 \mathrm{~g}\left(1.819 \times 10^{-4} \mathrm{~mol}\right)$ of 2 and $0.047 \mathrm{~g}$ $\left(1.819 \times 10^{-4} \mathrm{~mol}\right)$ of $\mathrm{PPh}_{3}$ dissolved together in $5 \mathrm{ml}$ of anhydrous $\mathrm{CH}_{2} \mathrm{Cl}_{2}$ were added under inert atmosphere $(\mathrm{Ar})$. The mixture was stirred for $15 \mathrm{~m}$ and then $\mathrm{AgBr}$ was filtered off with a millipore 
apparatus. The clear solution was evaporated to small volume under vacuum and treated with diethylether. The brown precipitate was filtered off on a gooch and washed with diethylether and pentane and dried under vacuum. $0.1053 \mathrm{~g}$ (73\% yield) of the title compound was obtained.

${ }^{1} \mathrm{H}$ NMR $\left(\mathrm{CD}_{2} \mathrm{Cl}_{2}, T=298 \mathrm{~K}, \mathrm{ppm}\right) \delta: 2.29\left(\mathrm{~s}, 6 \mathrm{H}\right.$, tol- $\left.\mathrm{CH}_{3}\right)$, 2.66-2.76 ( $\mathrm{m}, 4.25,2 \mathrm{H}, \mathrm{CH}=\mathrm{CH}$, trans- $\mathrm{C}$ and trans- $\mathrm{P}), 4.84$ (bs, $\left.4 \mathrm{H}, \mathrm{N}-\mathrm{CH}_{2}\right), 6.78(\mathrm{~s}, 2 \mathrm{H}, \mathrm{CH}=\mathrm{CH} \mathrm{Im}), 6.97-7.03(\mathrm{~m}, 8 \mathrm{H}$, tol-H $)$ 7.21-7.46 (m, 15H, PPh $).{ }^{1} \mathrm{H}$ NMR $\left(\mathrm{CD}_{2} \mathrm{Cl}_{2}, T=213 \mathrm{~K}, \mathrm{ppm}\right) \delta$ : $2.17\left(\mathrm{~s}, 3 \mathrm{H}\right.$, tol- $\left.\mathrm{CH}_{3}\right), 2.27\left(\mathrm{~s}, 3 \mathrm{H}\right.$, tol- $\left.\left.\mathrm{CH}_{3}\right),\right), 2.79$ (ABX system(A), $J_{\mathrm{HP}}=12.7 \mathrm{~Hz}, J_{\mathrm{HH}}=12.5 \mathrm{~Hz}, 1 \mathrm{H}, \mathrm{CH}=\mathrm{CH}$ trans $\left.-\mathrm{P}\right), 2.87$ (ABX system (B), $J_{\mathrm{HH}}=12.7 \mathrm{~Hz}, J_{\mathrm{HP}}=2.7 \mathrm{~Hz}, 1 \mathrm{H}, \mathrm{CH}=\mathrm{CH}$ trans $\left.-\mathrm{C}\right), 4.34(\mathrm{~d}$, $\left.J=14.4 \mathrm{~Hz}, 1 \mathrm{H}, \mathrm{N}-\mathrm{CH}_{2}\right), 4.48\left(\mathrm{~d}, J=14.1 \mathrm{~Hz}, 1 \mathrm{H}, \mathrm{N}-\mathrm{CH}_{2}\right), 4.91$ (d, $\left.J=14.4 \mathrm{~Hz}, 1 \mathrm{H}, \mathrm{N}-\mathrm{CH}_{2}\right), 4.93\left(\mathrm{~d}, J=14.1 \mathrm{~Hz}, 1 \mathrm{H}, \mathrm{N}-\mathrm{CH}_{2}\right), 6.71$ (d, $J=1.6 \mathrm{~Hz}, 1 \mathrm{H}, \mathrm{CH}=\mathrm{CH} \operatorname{Im}), 6.74(\mathrm{~d}, J=1.6 \mathrm{~Hz}, 1 \mathrm{H}, \mathrm{CH}=\mathrm{CH} \mathrm{Im})$, 6.79 (d, $J=7.8 \mathrm{~Hz}, 2 \mathrm{H}$, tol-H), 6.95 (d, $J=7.8 \mathrm{~Hz}, 2 \mathrm{H}$, tol-H), 6.94-7.02 (b AB system, $4 \mathrm{H}$, tol-H), 7.07-7.46 (m, 15H, $\left.\mathrm{PPh}_{3}\right)$.

${ }^{13} \mathrm{C}\left\{{ }^{1} \mathrm{H}\right\}$ NMR $\left(\mathrm{CD}_{2} \mathrm{Cl}_{2}, T=298 \mathrm{~K}, \mathrm{ppm}\right) \delta: 20.8\left(\mathrm{CH}_{3}\right.$, tol- $\left.\mathrm{CH}_{3}\right)$, $21.3\left(\mathrm{~d}, \mathrm{CH}, J_{\mathrm{CP}}=3.0 \mathrm{~Hz}, \mathrm{CH}=\mathrm{CH}\right.$ trans-C), $22.3\left(\mathrm{~d}, \mathrm{CH}, J_{\mathrm{CP}}=40.7\right.$ $\mathrm{Hz}, \mathrm{CH}=\mathrm{CH}$ trans-P $), 54.3\left(\mathrm{CH}_{2}, \mathrm{NCH}_{2}\right), 120.9(\mathrm{CH}, \mathrm{CH}=\mathrm{CH} \mathrm{Im})$, 123.7 (C, CN trans-C), 123.7 (d, C, $J_{\mathrm{CP}}=7.6 \mathrm{~Hz}, \mathrm{CN}$ trans $\left.-\mathrm{P}\right), 128.4$ $(\mathrm{CH}$, tol $o-\mathrm{C}), 129.3(\mathrm{CH}$, tol $m-\mathrm{C}), 133.1(\mathrm{C}$, tol $i-\mathrm{C}), 137.9(\mathrm{C}$, tol $p-\mathrm{C}), 188.5\left(\mathrm{C}, \mathrm{d}, J_{\mathrm{CP}}=12.0 \mathrm{~Hz}, \mathrm{NCN}\right) .{ }^{31} \mathrm{P}\left\{{ }^{1} \mathrm{H}\right\} \mathrm{NMR}\left(\mathrm{CD}_{2} \mathrm{Cl}_{2}, T=\right.$ $298 \mathrm{~K}, \mathrm{ppm}) \delta: 27.5$.

IR (KBr): $v_{\mathrm{CN}}=2196 \mathrm{~cm}^{-1}$.

Anal. Calc. for $\mathrm{C}_{43} \mathrm{H}_{43} \mathrm{~N}_{2} \mathrm{O}_{4}$ PPd: C, 65.36; $\mathrm{H}, 5.61 ; \mathrm{N}, 3.55$. Found: C, 65.49; H, 5.73; N, 3.61.

\subsubsection{Synthesis of complex $\mathbf{9 c}$}

To $0.064 \mathrm{~g}\left(1.10 \times 10^{-4} \mathrm{~mol}\right)$ of complex $1 \mathrm{c}$ dissolved in $10 \mathrm{ml}$ of anhydrous $\mathrm{CH}_{2} \mathrm{Cl}_{2}, 0.0411 \mathrm{~g}\left(1.10 \times 10^{-4} \mathrm{~mol}\right)$ of 3 and 0.0288 $\mathrm{g}\left(1.10 \times 10^{-4} \mathrm{~mol}\right)$ of $\mathrm{PPh}_{3}$ dissolved in $5 \mathrm{ml}$ of anhydrous $\mathrm{CH}_{2} \mathrm{Cl}_{2}$ were added under inert atmosphere $(\mathrm{Ar})$. The mixture was stirred for $15 \mathrm{~m}$ and then $\mathrm{AgBr}$ was filtered off with a millipore apparatus. The clear solution was evaporated to dryness under vacuum and the residue treated with diethylether. The whitish compound was filtered off on a gooch and washed with diethylether and pentane and dried under vacuum. $0.0741 \mathrm{~g}$ (83\% yield) of the title compound was obtained.

${ }^{1} \mathrm{H}$ NMR $\left(\mathrm{CDCl}_{3}, T=298 \mathrm{~K}, \mathrm{ppm}\right) \delta: 2.24\left(\mathrm{~s}, 3 \mathrm{H}, \mathrm{OCH}_{3}\right), 3.32(\mathrm{~s}$, $\left.3 \mathrm{H}, \mathrm{OCH}_{3}\right), 3.34\left(\mathrm{~s}, 3 \mathrm{H}, \mathrm{NCH}_{3}\right), 3.44\left(\mathrm{~s}, 3 \mathrm{H}, \mathrm{OCH}_{3}\right), 3.55(\mathrm{~s}, 3 \mathrm{H}$, $\left.\mathrm{OCH}_{3}\right), 3.66\left(\mathrm{~s}, 3 \mathrm{H}, \mathrm{OCH}_{3}\right), 4.83\left(\mathrm{~d}, J=14.4 \mathrm{~Hz}, 1 \mathrm{H}, \mathrm{N}-\mathrm{CH}_{2}\right), 5.067$ $\left(\mathrm{d}, J=14.4 \mathrm{~Hz}, 1 \mathrm{H}, \mathrm{N}-\mathrm{CH}_{2}\right), 6.65(\mathrm{~s}, 2 \mathrm{H}, \mathrm{CH}=\mathrm{CH} \mathrm{Im}), 6.85,6.95$ (AB system, $J=8.1 \mathrm{~Hz}, 4 \mathrm{H}$, tol $m-\mathrm{H}$, tol $o-\mathrm{H}$, ) 7.18-7.37 $(\mathrm{m}, 15 \mathrm{H}$, $\left.\mathrm{PPh}_{3}\right)$.

${ }^{13} \mathrm{C}\left\{{ }^{1} \mathrm{H}\right\}$ NMR $\left(\mathrm{CDCl}_{3}, T=298 \mathrm{~K}, \mathrm{ppm}\right) \delta: 21.5\left(\mathrm{CH}_{3}\right.$, tol $\left.-\mathrm{CH}_{3}\right), 37.6$ $\left(\mathrm{CH}_{3}, \mathrm{NCH}_{3}\right), 51.6\left(\mathrm{CH}_{3}, \mathrm{OCH}_{3}\right), 51.9\left(\mathrm{CH}_{3}, \mathrm{OCH}_{3}\right), 52.2\left(\mathrm{CH}_{3}, \mathrm{OCH}_{3}\right)$, $52.3\left(\mathrm{CH}_{3}, \mathrm{OCH}_{3}\right), 54.4\left(\mathrm{CH}_{2}, \mathrm{NCH}_{2}\right), 120.6(\mathrm{CH}, \mathrm{CH}=\mathrm{CH} \mathrm{Im}), 122.2$ $(\mathrm{CH}, \mathrm{CH}=\mathrm{CH} \mathrm{Im}), 129.3(\mathrm{CH}$, tol $o-\mathrm{C}), 129.6(\mathrm{CH}$, tol $m-\mathrm{C}), 133.5(\mathrm{C}$, tol $i-C), 137.9(\mathrm{C}$, tol $p-\mathrm{C}), 170.7(\mathrm{C}, \mathrm{CO}), 170.9\left(\mathrm{C}, \mathrm{d}, J_{\mathrm{CP}}=4.8 \mathrm{~Hz}, \mathrm{CO}\right)$, 171.0 (C, CO), 171.3 (C, d, $\left.J_{\mathrm{CP}}=4.4 \mathrm{~Hz}, \mathrm{CO}\right), 187.4$ (C, d, $J_{\mathrm{CP}}=16.7 \mathrm{~Hz}$, NCN).

${ }^{31} \mathrm{P}\left\{{ }^{1} \mathrm{H}\right\} \mathrm{NMR}\left(\mathrm{CDCl}_{3}, T=298 \mathrm{~K}, \mathrm{ppm}\right) \delta: 30.0$.

IR (KBr): $v_{\mathrm{C}=\mathrm{O}}=1731,1711,1692,1675 \mathrm{~cm}^{-1}$.

Anal. Calc. for $\mathrm{C}_{40} \mathrm{H}_{41} \mathrm{~N}_{2} \mathrm{O}_{8}$ PPd: C, 58.86; H, 5.19; N, 3.43. Found: C, 59.02; H, 5.21; N, 3.32.

\subsubsection{Synthesis of complex 11c}

To $0.064 \mathrm{~g}\left(1.10 \times 10^{-4} \mathrm{~mol}\right)$ of complex 1c dissolved in $10 \mathrm{ml}$ of anhydrous $\mathrm{CH}_{2} \mathrm{Cl}_{2}, 0.0396 \mathrm{~g}\left(1.10 \times 10^{-4} \mathrm{~mol}\right)$ of 4 and $0.0288 \mathrm{~g}$ $\left(1.10 \times 10^{-4} \mathrm{~mol}\right)$ of $\mathrm{PPh}_{3}$ dissolved in $5 \mathrm{ml}$ of anhydrous $\mathrm{CH}_{2} \mathrm{Cl}_{2}$ were added under inert atmosphere $(\mathrm{Ar})$. The mixture was stirred for $15 \mathrm{~m}$ and then $\mathrm{AgBr}$ was filtered off with a millipore apparatus. The clear solution was evaporated to dryness under vacuum and the residue treated with diethylether. The whitish compound was filtered off on a gooch and washed with diethylether and pentane and dried under vacuum. $0.0741 \mathrm{~g}$ (83\% yield) of the title compound was obtained.

${ }^{1} \mathrm{H} \mathrm{NMR}\left(\mathrm{CDCl}_{3}, T=298 \mathrm{~K}, \mathrm{ppm}\right) \delta: 3.31\left(\mathrm{~s}, 3 \mathrm{H}, \mathrm{OCH}_{3}\right), 3.36(\mathrm{~s}$, $\left.3 \mathrm{H}, \mathrm{NCH}_{3}\right), 3.43\left(\mathrm{~s}, 3 \mathrm{H}, \mathrm{OCH}_{3}\right), 3.53\left(\mathrm{~s}, 3 \mathrm{H}, \mathrm{OCH}_{3}\right), 3.67(\mathrm{~s}, 3 \mathrm{H}$, $\left.\mathrm{OCH}_{3}\right), 4.86\left(\mathrm{~d}, \mathrm{~J}=14.4 \mathrm{~Hz}, 1 \mathrm{H}, \mathrm{N}-\mathrm{CH}_{2}\right), 5.14(\mathrm{~d}, J=14.4 \mathrm{~Hz}, 1 \mathrm{H}, \mathrm{N}-$ $\mathrm{CH}_{2}$ ), 6.65,6.67 (AB system, $J=1.8 \mathrm{~Hz}, 2 \mathrm{H}, \mathrm{CH}=\mathrm{CH} \mathrm{Im}$ ), 7.03-7.36 $\left(\mathrm{m}, 2 \mathrm{H}, \mathrm{Ph} m-\mathrm{H}, \mathrm{Ph} o-\mathrm{H}, \mathrm{Ph} p-\mathrm{H}, \mathrm{PPh}_{3}\right)$.

${ }^{13} \mathrm{C}\left\{{ }^{1} \mathrm{H}\right\}$ NMR $\left(\mathrm{CDCl}_{3}, T=298 \mathrm{~K}, \mathrm{ppm}\right) \delta: 37.6\left(\mathrm{CH}_{3}, \mathrm{NCH}_{3}\right), 51.6$ $\left(\mathrm{CH}_{3}, \mathrm{OCH}_{3}\right), 51.8\left(\mathrm{CH}_{3}, \mathrm{OCH}_{3}\right), 52.2\left(\mathrm{CH}_{3}, \mathrm{OCH}_{3}\right), 52.3\left(\mathrm{CH}_{3}\right.$, $\left.\mathrm{OCH}_{3}\right), 54.7\left(\mathrm{CH}_{2}, \mathrm{NCH}_{2}\right), 120.6(\mathrm{CH}, \mathrm{CH}=\mathrm{CH} \mathrm{Im}), 122.3(\mathrm{CH}, \mathrm{CH}$ $=\mathrm{CH} \mathrm{Im}), 128.2(\mathrm{CH}, \mathrm{Ph} p-\mathrm{C}), 129.0(\mathrm{CH}, \mathrm{Ph} m-\mathrm{C}), 129.3(\mathrm{CH}, \mathrm{Ph}$ $o-\mathrm{C}$ ), 136.5 (C, Ph i-C), 170.7 (C,CO), 170.9 (C, d, $J_{\mathrm{CP}}=4.6 \mathrm{~Hz}, \mathrm{CO}$ ), 171.0 (C, CO), 171.1 (C, d, $J_{\mathrm{CP}}=4.3 \mathrm{~Hz}, \mathrm{CO}$ ), 187.7 (C, d, $J_{\mathrm{CP}}=16.3$ $\mathrm{Hz}, \mathrm{NCN})$.

${ }^{31} \mathrm{P}\left\{{ }^{1} \mathrm{H}\right\}$ NMR $\left(\mathrm{CDCl}_{3}, \mathrm{~T}=298 \mathrm{~K}, \mathrm{ppm}\right) \delta: 30.0$.

IR $(\mathrm{KBr}): v_{\mathrm{C}=\mathrm{O}}=1711,1681 \mathrm{~cm}^{-1}$.

Anal. Calc. for $\mathrm{C}_{39} \mathrm{H}_{39} \mathrm{~N}_{2} \mathrm{O}_{8}$ PPd: C, 58.40; $\mathrm{H}, 5.03 ; \mathrm{N}, 3.49$. Found: C, 58.51; H, 5.12; N, 3.47.

\subsection{Mixed PTA-NHC complexes}

\subsubsection{Synthesis of complex $7 \boldsymbol{a}$}

To $0.062 \mathrm{~g}\left(1.548 \times 10^{-4} \mathrm{~mol}\right)$ of complex $1 \mathrm{a}$ dissolved in $10 \mathrm{ml}$ of anhydrous $\mathrm{CH}_{2} \mathrm{Cl}_{2}, 0.0719 \mathrm{~g}\left(1.548 \times 10^{-4} \mathrm{~mol}\right)$ of 2 and 0.0243 $\mathrm{g}\left(1.548 \times 10^{-4} \mathrm{~mol}\right)$ of PTA suspended in $5 \mathrm{ml}$ of anhydrous $\mathrm{CH}_{2}-$ $\mathrm{Cl}_{2}$ were added under inert atmosphere $(\mathrm{Ar})$. The mixture was stirred for $15 \mathrm{~m}$ and then $\mathrm{AgBr}$ was filtered off with a millipore apparatus. The clear solution was evaporated to dryness under vacuum and the residue treated with diethylether. The whitish compound was filtered off on a gooch and washed with diethylether and pentane and dried under vacuum. $0.0801 \mathrm{~g}$ ( $81 \%$ yield) of the title compound was obtained.

${ }^{1} \mathrm{H}$ NMR $\left(\mathrm{CD}_{2} \mathrm{Cl}_{2}, T=298 \mathrm{~K}, \mathrm{ppm}\right) \delta: 2.37\left(\mathrm{~s}, 6 \mathrm{H}\right.$, tol- $\left.\mathrm{CH}_{3}\right), 3.73-$ $3.79(\mathrm{~m}, 4.25,2 \mathrm{H}, \mathrm{CH}=\mathrm{CH}$, trans $-\mathrm{C}$ and trans $-\mathrm{P}), 3.59(\mathrm{~d}, J=2.7 \mathrm{~Hz}$, $6 \mathrm{H}, \mathrm{NCH}_{2} \mathrm{P}$ ), 4,27, 4.40 (AB system, $J=13.0 \mathrm{~Hz}, 6 \mathrm{H}, \mathrm{NCH}_{2} \mathrm{~N}$ ), 5,07, 5.11 (AB system, $\left.J=15.0 \mathrm{~Hz}, 4 \mathrm{H}, \mathrm{NCH}_{2}\right), 7.10(\mathrm{~s}, 2 \mathrm{H}, \mathrm{CH}=\mathrm{CH} \mathrm{Im})$, 7.12-7.26 (m, 8H, tol-H).

${ }^{13} \mathrm{C}\left\{{ }^{1} \mathrm{H}\right\}$ NMR $\left(\mathrm{CD}_{2} \mathrm{Cl}_{2}, \mathrm{~T}=298 \mathrm{~K}, \mathrm{ppm}\right) \delta: 20.8\left(\mathrm{CH}_{3}\right.$, tol- $\left.\mathrm{CH}_{3}\right)$, $42.7\left(\mathrm{CH}, \mathrm{CH}=\mathrm{CH}\right.$ trans-C), $45.4\left(\mathrm{CH}, \mathrm{d}, J_{\mathrm{CP}}=28.6 \mathrm{~Hz}, \mathrm{CH}=\mathrm{CH}\right.$ trans-P), $52.3\left(\mathrm{CH}_{2}, \mathrm{~d}, J=6.7 \mathrm{~Hz}, \mathrm{NCH}_{2} \mathrm{P}\right), 54.5\left(\mathrm{CH}_{2}, \mathrm{NCH}_{2}\right), 73.1$ $\left(\mathrm{CH}_{2}, \mathrm{~d}, J_{\mathrm{CP}}=5.6 \mathrm{~Hz}, \mathrm{NCH}_{2} \mathrm{~N},\right) 121.8(\mathrm{CH}, \mathrm{CH}=\mathrm{CH} \mathrm{Im}), 127.7(\mathrm{CH}$, tol o-C), 129.5 ( $\mathrm{CH}$, tol $m-\mathrm{C}$ ), 134.0 (C, tol $i-\mathrm{C}$ ), 138.0 (C, tol $p-\mathrm{C}$ ), $188.8\left(\mathrm{C}, \mathrm{d}, J_{\mathrm{CP}}=14.2 \mathrm{~Hz}, \mathrm{NCN}\right)$.

${ }^{31} \mathrm{P}\left\{{ }^{1} \mathrm{H}\right\}$ NMR $\left(\mathrm{CD}_{2} \mathrm{Cl}_{2}, T=298 \mathrm{~K}, \mathrm{ppm}\right) \delta:-60.4$.

IR $(\mathrm{KBr}): v_{\mathrm{C}=\mathrm{O}}=1781-1717 \mathrm{~cm}^{-1}$.

Anal. Calc. for $\mathrm{C}_{29} \mathrm{H}_{34} \mathrm{~N}_{5} \mathrm{O}_{3}$ PPd: C, 54.51; H, 5.52; N, 10.96 . Found: C, 54.63; H, 5.47; N, 11.05 .

Derivatives $\mathbf{7 b}$-c, were prepared in a similar way using the appropriate reactants.

\subsubsection{Synthesis of complex $\mathbf{7 b}$}

Whitish microcrystals: Yield $83 \%$.

${ }^{1} \mathrm{H}$ NMR $\left(\mathrm{CD}_{2} \mathrm{Cl}_{2}, T=298 \mathrm{~K}, \mathrm{ppm}\right) \delta: 2.38\left(\mathrm{~s}, 6 \mathrm{H}\right.$, tol- $\left.\mathrm{CH}_{3}\right), 2.51$ $\left(\mathrm{dd}, J_{\mathrm{HP}}=9.7 \mathrm{~Hz}, J_{\mathrm{HH}}=9.7 \mathrm{~Hz}, 1 \mathrm{H}, \mathrm{CH}=\mathrm{CH}\right.$ trans-P), $2.66\left(\mathrm{dd}, J_{\mathrm{HH}}\right.$ $=9.9 \mathrm{~Hz}, J_{\mathrm{HP}}=3.9 \mathrm{~Hz}, 1 \mathrm{H}, \mathrm{CH}=\mathrm{CH}$ trans $\left.-\mathrm{C}\right), 3.69(\mathrm{~d}, J=2.9 \mathrm{~Hz}, 6 \mathrm{H}$, $\left.\mathrm{NCH}_{2} \mathrm{P}\right), 4,32,4.44\left(\mathrm{AB}\right.$ system, $\left.J=13.0 \mathrm{~Hz}, 6 \mathrm{H}, \mathrm{NCH}_{2} \mathrm{~N}\right), 5,15,4.23$ (AB system, $\left.J=14.9 \mathrm{~Hz}, 4 \mathrm{H}, \mathrm{NCH}_{2}\right), 7.11(\mathrm{~s}, 2 \mathrm{H}, \mathrm{CH}=\mathrm{CH} \mathrm{Im})$, 7.16-7.27 ( $\mathrm{m}, 8 \mathrm{H}$, tol-H).

${ }^{13} \mathrm{C}\left\{{ }^{1} \mathrm{H}\right\}$ NMR $\left(\mathrm{CD}_{2} \mathrm{Cl}_{2}, T=298 \mathrm{~K}, \mathrm{ppm}\right) \delta: 18.2\left(\mathrm{~d}, \mathrm{CH}, J_{\mathrm{CP}}=3.6\right.$ $\mathrm{Hz}, \mathrm{CH}=\mathrm{CH}$ trans-C $), 20.8\left(\mathrm{CH}_{3}\right.$, tol- $\left.\mathrm{CH}_{3}\right), 20.3\left(\mathrm{CH}, \mathrm{d}, J_{\mathrm{CP}}=39.6\right.$ $\mathrm{Hz}, \mathrm{CH}=\mathrm{CH}$ trans- $\mathrm{P}), 52.6$ partially obscured by $\mathrm{CD}_{2} \mathrm{Cl}_{2}\left(\mathrm{CH}_{2}, \mathrm{NCH}_{2}-\right.$ P), $54.5\left(\mathrm{CH}_{2}, \mathrm{NCH}_{2}\right), 73.1\left(\mathrm{CH}_{2}, \mathrm{~d}, J_{\mathrm{CP}}=5.6 \mathrm{~Hz}, \mathrm{NCH}_{2} \mathrm{~N}\right), 121.7(\mathrm{CH}$, $\mathrm{CH}=\mathrm{CH} \mathrm{Im}), 123.2\left(\mathrm{C}, J_{\mathrm{CP}}=2.7 \mathrm{~Hz}, \mathrm{CN}\right.$ trans-C $), 124.2\left(\mathrm{~d}, \mathrm{C}, J_{\mathrm{CP}}=8.1\right.$ $\mathrm{Hz}, \mathrm{CN}$ trans-P), 127.7 (CH, tol o-C), $129.5(\mathrm{CH}$, tol $m-\mathrm{C}), 134.1$ (C, tol $i-\mathrm{C}), 138.0(\mathrm{C}$, tol $p-\mathrm{C}), 172.5\left(\mathrm{C}, \mathrm{d}, J_{\mathrm{CP}}=5.1 \mathrm{~Hz}, \mathrm{CO}\right.$ CO trans-P), 172.8 (C, CO trans-C), $188.4\left(\mathrm{C}, \mathrm{d}, J_{\mathrm{CP}}=11.3 \mathrm{~Hz}, \mathrm{NCN}\right)$. 
${ }^{31} \mathrm{P}\left\{{ }^{1} \mathrm{H}\right\} \operatorname{NMR}\left(\mathrm{CD}_{2} \mathrm{Cl}_{2}, T=298 \mathrm{~K}, \mathrm{ppm}\right) \delta:-62.0$.

IR $(\mathrm{KBr}): v_{\mathrm{CN}}=2190 \mathrm{~cm}^{-1}$.

Anal. Calc. for $\mathrm{C}_{29} \mathrm{H}_{34} \mathrm{~N}_{7} \mathrm{PPd}$ : C, 56.27; $\mathrm{H}, 5.70 ; \mathrm{N}, 15.84$. Found: C, 56.13; H, 5.82; N, 15.71 .

\subsubsection{Synthesis of complex 7c}

Whitish microcrystals: Yield $92 \%$.

${ }^{1} \mathrm{H} \mathrm{NMR}\left(\mathrm{CD}_{2} \mathrm{Cl}_{2}, T=298 \mathrm{~K}, \mathrm{ppm}\right) \delta: 2.38\left(\mathrm{~s}, 6 \mathrm{H}\right.$, tol $\left.-\mathrm{CH}_{3}\right), 3.37(\mathrm{~d}$, $\left.J=1.9 \mathrm{~Hz}, 6 \mathrm{H}, \mathrm{NCH}_{2} \mathrm{P}\right) 3.56\left(\mathrm{~s}, 6 \mathrm{H}, \mathrm{OCH}_{3}\right), 3.70\left(\mathrm{~s}, 6 \mathrm{H}, \mathrm{OCH}_{3}\right), 4,12$, 4.32 (AB system, $\left.J=13.0 \mathrm{~Hz}, 6 \mathrm{H}, \mathrm{NCH}_{2} \mathrm{~N}\right) 5.09(\mathrm{~d}, J=15.0 \mathrm{~Hz}, 2 \mathrm{H}$, $\left.\mathrm{N}-\mathrm{CH}_{2}\right), 5.35\left(\mathrm{~d}, \mathrm{~J}=15.0 \mathrm{~Hz}, 2 \mathrm{H}, \mathrm{N}-\mathrm{CH}_{2}\right), 7.11(\mathrm{~s}, 2 \mathrm{H}, \mathrm{CH}=\mathrm{CH} \mathrm{Im})$, 7.19-7.26 ( $\mathrm{m}, 8 \mathrm{H}$, tol-H).

${ }^{13} \mathrm{C}\left\{{ }^{1} \mathrm{H}\right\}$ NMR $\left(\mathrm{CD}_{2} \mathrm{Cl}_{2}, T=298 \mathrm{~K}, \mathrm{ppm}\right) \delta: 20.8\left(\mathrm{CH}_{3}\right.$, tol- $\left.\mathrm{CH}_{3}\right)$, $51.6\left(\mathrm{CH}_{3}, \mathrm{OCH}_{3}\right), 51.7\left(\mathrm{CH}_{3}, \mathrm{OCH}_{3}\right), 51.9\left(\mathrm{CH}_{2}, \mathrm{~d}, J_{\mathrm{CP}}=7.3 \mathrm{~Hz}, \mathrm{NCH}_{2^{-}}\right.$ P), $54.0\left(\mathrm{CH}_{2}, \mathrm{NCH}_{2}\right), 72.9\left(\mathrm{CH}_{2}, \mathrm{~d}, J_{\mathrm{CP}}=5.8 \mathrm{~Hz}, \mathrm{NCH}_{2} \mathrm{~N}\right) 121.6(\mathrm{CH}$, $\mathrm{CH}=\mathrm{CH} \mathrm{Im}), 128.0(\mathrm{CH}$, tol o-C), $129.4(\mathrm{CH}$, tol $m-\mathrm{C}), 134.3(\mathrm{C}$, tol $i-\mathrm{C}), 137.8$ (C, tol $p-\mathrm{C}), 170.0\left(\mathrm{C}, \mathrm{d}, J_{\mathrm{CP}}=4.9 \mathrm{~Hz}, \mathrm{CO}\right.$ CO trans-P), 170.2 (C, CO trans-C), $187.2\left(\mathrm{C}, \mathrm{d}, J_{\mathrm{CP}}=16.0 \mathrm{~Hz}, \mathrm{NCN}\right)$.

${ }^{31} \mathrm{P}\left\{{ }^{1} \mathrm{H}\right\} \operatorname{NMR}\left(\mathrm{CD}_{2} \mathrm{Cl}_{2}, T=298 \mathrm{~K}, \mathrm{ppm}\right) \delta:-57.7$.

IR $(\mathrm{KBr}): v_{\mathrm{C}=\mathrm{O}}=1720-1678 \mathrm{~cm}^{-1}$.

Anal. Calc. for $\mathrm{C}_{35} \mathrm{H}_{44} \mathrm{~N}_{5} \mathrm{O}_{8}$ PPd: C, 52.47; $\mathrm{H}, 5.66 ; \mathrm{N}, 8.74$. Found: C, 52.36; H, 5.61; N, 8.84.

\subsection{Mixed DIC-NHC complexes}

\subsubsection{Synthesis of complex $\boldsymbol{8 b}$}

To $0.080 \mathrm{~g}\left(1.997 \times 10^{-4} \mathrm{~mol}\right)$ of complex $\mathbf{1 b}$ dissolved in $10 \mathrm{ml}$ of anhydrous $\mathrm{CH}_{2} \mathrm{Cl}_{2}, 0.0927 \mathrm{~g}\left(1.997 \times 10^{-4} \mathrm{~mol}\right)$ of 2 and 0.0262 $\mathrm{g}\left(1.997 \times 10^{-4} \mathrm{~mol}\right)$ of DIC dissolved together in $5 \mathrm{ml}$ of anhydrous $\mathrm{CH}_{2} \mathrm{Cl}_{2}$ were added under inert atmosphere (Ar). The mixture was stirred for $15 \mathrm{~m}$ and then $\mathrm{AgBr}$ was filtered off with a millipore apparatus. The clear solution was evaporated to dryness under vacuum and the residue treated with diethylether. The white compound was filtered off on a gooch and washed with diethylether and pentane and dried under vacuum. $0.1058 \mathrm{~g}$ (90\% yield) of the title compound was obtained.

${ }^{1} \mathrm{H}$ NMR $\left(\mathrm{CD}_{2} \mathrm{Cl}_{2}, T=298 \mathrm{~K}, \mathrm{ppm}\right) \delta: 2.25\left(\mathrm{~s}, 6 \mathrm{H}\right.$, tol $\left.-\mathrm{CH}_{3}\right), 2.28(\mathrm{~s}$, $\left.6 \mathrm{H}, \mathrm{DIC}-\mathrm{CH}_{3}\right), 2.59(\mathrm{~d}, J=9.4 \mathrm{~Hz}, 1 \mathrm{H}, \mathrm{CH}=\mathrm{CH}), 2.86(\mathrm{~d}, J=9.4 \mathrm{~Hz}$, $1 \mathrm{H}, \mathrm{CH}=\mathrm{CH}$ ), $5.29,5.43$ (AB system, $J=14.9 \mathrm{~Hz}, 4 \mathrm{H}, \mathrm{N}-\mathrm{CH}_{2}$ ), 7.05 $(\mathrm{s}, 2 \mathrm{H}, \mathrm{CH}=\mathrm{CH} \mathrm{Im}), 7.10-7.25(\mathrm{~m}, 16 \mathrm{H}$, tol-H, DIC-H).

${ }^{13} \mathrm{C}\left\{{ }^{1} \mathrm{H}\right\}$ NMR $\left(\mathrm{CD}_{2} \mathrm{Cl}_{2}, T=298 \mathrm{~K}, \mathrm{ppm}\right) \delta: 18.4\left(\mathrm{CH}_{3}, \mathrm{DIC}-\mathrm{CH}_{3}\right)$, $19.0(\mathrm{CH}, \mathrm{CH}=\mathrm{CH}), 20.4(\mathrm{CH}, \mathrm{CH}=\mathrm{CH}), 20.7\left(\mathrm{CH}_{3}\right.$, tol- $\left.\mathrm{CH}_{3}\right), 54.5$ $\left(\mathrm{CH}_{2}, \mathrm{NCH}_{2}\right), 121.5(\mathrm{CH}, \mathrm{CH}=\mathrm{CH} \mathrm{Im}), 123.4(\mathrm{C}, \mathrm{CN}), 123.6(\mathrm{C}, \mathrm{CN})$, $127.7(\mathrm{CH}$, tol $o-\mathrm{C}), 127.7$ (CH, m-DIC), 128.7 ( $\mathrm{CH}, p$-DIC), 129.3 (CH, tol m-C), 133.9 (C, tol $i-\mathrm{C}$ ), 134.8 (C, o-DIC), 137.8 (C, tol pC), $187.5(\mathrm{C}, \mathrm{NCN})$.

IR $(\mathrm{KBr}): v_{\mathrm{CN}}=2196-2134 \mathrm{~cm}^{-1}$.

Anal. Calc. for $\mathrm{C}_{32} \mathrm{H}_{31} \mathrm{~N}_{5} \mathrm{Pd}$ : C, 64.92; H, 5.28; N, 11.83. Found: C, 65.10; H, 5.31; N, 11.99

Derivatives $\mathbf{8 c}$ and $\mathbf{1 0 c}$ were prepared in a similar way using the appropriate reactants.

\subsubsection{Synthesis of complex 8c}

Whitish microcrystals; Yield 93\%.

${ }^{1} \mathrm{H} \mathrm{NMR}\left(\mathrm{CDCl}_{3}, T=298 \mathrm{~K}, \mathrm{ppm}\right) \delta: 2.12$ (bs, $12 \mathrm{H}$, tolyl- $\mathrm{CH}_{3}$, aryl$\left.\mathrm{CH}_{3}\right), 3.63\left(\mathrm{~s}, 6 \mathrm{H}, \mathrm{OCH}_{3}\right), 3.71\left(\mathrm{~s}, 6 \mathrm{H}, \mathrm{OCH}_{3}\right), 4.63\left(\mathrm{~s}, 4 \mathrm{H}, \mathrm{N}-\mathrm{CH}_{2}\right)$, $6.92(\mathrm{~s}, 2 \mathrm{H}, \mathrm{CH}=\mathrm{CH} \mathrm{Im}), 6.99(\mathrm{~d}, J=7.8 \mathrm{~Hz}, 2 \mathrm{H}$, tolyl $m-\mathrm{H}), 7.04$ $(\mathrm{d}, J=7.5 \mathrm{~Hz}, 2 \mathrm{H}$, aryl $m-\mathrm{H}), 7.13-7.18(\mathrm{~m}, 3 \mathrm{H}$, tolyl $o-\mathrm{H}$, aryl $p-\mathrm{H})$.

${ }^{13} \mathrm{C}\left\{{ }^{1} \mathrm{H}\right\}$ NMR $\left(\mathrm{CDCl}_{3}, T=298 \mathrm{~K}, \mathrm{ppm}\right) \delta: 18.8\left(\mathrm{CH}_{3}\right.$, aryl- $\left.\mathrm{CH}_{3}\right)$, $21.3\left(\mathrm{CH}_{3}, \mathrm{Ph}-\mathrm{CH}_{3}\right), 52.3\left(\mathrm{CH}_{3}, \mathrm{OCH}_{3}\right), 52.4\left(\mathrm{CH}_{3}, \mathrm{OCH}_{3}\right), 54.8$ $\left(\mathrm{CH}_{2}, \mathrm{NCH}_{2}\right), 121.5(\mathrm{CH}, \mathrm{CH}=\mathrm{CH} \mathrm{Im}), 127.9(\mathrm{CH}$, aryl $m-\mathrm{C}), 128.6$ $(\mathrm{CH}$, tolyl $o-\mathrm{C}), 128.9(\mathrm{CH}$, aryl $p-\mathrm{C}), 129.4(\mathrm{CH}$, tolyl $m-\mathrm{C}), 134.6$ (C, tolyl $i-\mathrm{C}$ ), 135.4 (C, aryl o-C), 137.8 (C, tolyl p-C), 157.3 (C, CN), 170.6 (C, CO), 170.9 (C, CO), 186.7 (C, NCN).

IR $(\mathrm{KBr}): v_{\mathrm{C}=\mathrm{O}}=1685,1706,1725 \mathrm{~cm}^{-1}, v_{\mathrm{CN}}=2141 \mathrm{~cm}^{-1}$.
Anal. Calc. for $\mathrm{C}_{38} \mathrm{H}_{41} \mathrm{~N}_{3} \mathrm{O}_{8} \mathrm{Pd}$ : C, 58.95; $\mathrm{H}, 5.34 ; \mathrm{N}, 5.43$. Found: C, 59.07; H, 5.51; N, 5.36.

\subsubsection{Synthesis of complex 10c}

Whitish microcrystals; Yield 73\%.

${ }^{1} \mathrm{H}$ NMR $\left(\mathrm{CDCl}_{3}, T=298 \mathrm{~K}, \mathrm{ppm}\right) \delta: 2.13\left(\mathrm{~s}, 3 \mathrm{H}\right.$, tolyl- $\left.\mathrm{CH}_{3}\right), 2.34$ $\left(\mathrm{s}, 6 \mathrm{H}\right.$, aryl- $\left.\mathrm{CH}_{3}\right), 3.63\left(\mathrm{~s}, 6 \mathrm{H}, \mathrm{OCH}_{3}\right), 3.70\left(\mathrm{~s}, 6 \mathrm{H}, \mathrm{OCH}_{3}\right), 3.82(\mathrm{~s}$, $\left.3 \mathrm{H}, \mathrm{N}-\mathrm{CH}_{3}\right), 5.32\left(\mathrm{~s}, 2 \mathrm{H}, \mathrm{N}-\mathrm{CH}_{2}\right), 6.91(\mathrm{~d}, J=1.8 \mathrm{~Hz}, 1 \mathrm{H}, \mathrm{CH}=\mathrm{CH}$ Im), $6.94(\mathrm{~d}, J=1.8 \mathrm{~Hz}, 1 \mathrm{H}, \mathrm{CH}=\mathrm{CH} \mathrm{Im}), 6.98(\mathrm{~d}, J=7.8 \mathrm{~Hz}, 2 \mathrm{H}$, tolyl $m-\mathrm{H}), 7.06(\mathrm{~d}, J=7.8 \mathrm{~Hz}, 2 \mathrm{H}$, aryl $m-\mathrm{H}), 7.15-7.17(\mathrm{~m}, 3 \mathrm{H}$, tolyl $o-\mathrm{H}$, aryl $p-\mathrm{H})$.

${ }^{13} \mathrm{C}\left\{{ }^{1} \mathrm{H}\right\}$ NMR $\left(\mathrm{CDCl}_{3}, \mathrm{~T}=298 \mathrm{~K}, \mathrm{ppm}\right) \delta: 18.9\left(\mathrm{CH}_{3}\right.$, aryl- $\left.\mathrm{CH}_{3}\right)$, $21.3\left(\mathrm{CH}_{3}, \mathrm{Ph}-\mathrm{CH}_{3}\right), 38.3\left(\mathrm{CH}_{3}, \mathrm{NCH}_{3}\right) 52.3\left(\mathrm{CH}_{3}, \mathrm{OCH}_{3}\right), 52.3\left(\mathrm{CH}_{3}\right.$ $\left.\mathrm{OCH}_{3}\right), 54.6\left(\mathrm{CH}_{2}, \mathrm{NCH}_{2}\right), 121.3(\mathrm{CH}, \mathrm{CH}=\mathrm{CH} \mathrm{Im}), 122.4(\mathrm{CH}, \mathrm{CH}$ $=\mathrm{CH} \operatorname{Im}), 128.0(\mathrm{CH}$, aryl $m-\mathrm{C}), 128.5(\mathrm{CH}$, tolyl $o-\mathrm{C}), 129.5(\mathrm{CH}$, aryl $p$-C), 129.6 (CH, tolyl $m-\mathrm{C}), 134.6$ (C, tolyl $i-\mathrm{C}), 135.3$ (C, aryl o-C), 137.8 (C, tolyl p-C), 157.5 (C, CN), 170.6 (C,CO), 170.8 (C, CO), $186.5(\mathrm{C}, \mathrm{NCN})$.

IR $(\mathrm{KBr}): v_{\mathrm{C}=\mathrm{O}}=1689,1723 \mathrm{~cm}^{-1}, v_{\mathrm{CN}}=2137 \mathrm{~cm}^{-1}$.

Anal. Calc. for $\mathrm{C}_{31} \mathrm{H}_{35} \mathrm{~N}_{3} \mathrm{O}_{8} \mathrm{Pd}$ : C, 54.43; $\mathrm{H}, 5.16 ; \mathrm{N}, 6.14$. Found: C, 54.35; H, 5.27; N, 6.12 .

\section{Appendix A. Supplementary data}

CCDC 1581529 and 1581530 contains the supplementary crystallographic data for this paper. These data can be obtained free of charge via http://www.ccdc.cam.ac.uk/conts/retrieving.html, or from the Cambridge Crystallographic Data Centre, 12 Union Road, Cambridge CB2 1EZ, UK; fax: (+44) 1223-336-033; or e-mail: deposit@ccdc.cam.ac.uk. Supplementary data associated with this article can be found, in the online version, at https://doi.org/10. 1016/j.poly.2018.01.010.

\section{References}

[1] (a) D.S. McGuinness, W. Mueller, P. Wasserscheid, K.J. Cavell, B.W. Skelton, A. H. White, Organometallics 21 (2002) 175;

(b) D.J. Nielsen, K.J. Cavell, B.W. Skelton, A.H. White, Inorg. Chim. Acta 327 (2002) 116;

(c) R.E. Doutwhite, M. Green, P.J. Silkock, P.T. Gomes, J. Chem. Soc. Dalton Trans. (2002) 1386;

(d) W.A. Hermann, L.J. Goossen, M. Spiegler, Organometallics 17 (1998) 2162.

[2] (a) J.-Y. Lee, J.-S. Shen, R.-J. Tzeng, I.-C. Lu, J.-H. Lii, C.-H. Hu, H.M. Lee, Dalton Trans 45 (2016) 10375;

(b) Y.-M. Jhou, D. Nandi, J.-Y. Lee, R.J. Tzeng, H.M. Lee, Polyhedron 100 (2015) 28;

(c) M.B. Ansell, D.E. Roberts, F.G.N. Cloke, O. Navarro, J. Spencer, Angew. Chem., Int. Ed. 54 (2015) 5578;

(d) P. Nägele, U. Herrlich, F. Rominger, P. Hoffman, Organometallics 32 (2013) 181 ;

(e) D. Krishnan, M. Wu, M. Chiang, Y. Li, P.-H. Leung, S.A. Pullarkat, Organometallics 32 (2013) 2389;

(f) J.-Y. Lee, P.-Y. Cheng, Y.-H. Tsai, G.-R. Lin, S.-P. Liu, M.-H. Sie, H.M. Lee, Organometallics 29 (2010) 3901:

(g) S. Warsink, I.-H. Cahng, J.J. Weigand, P. Hauwert, J.-T. Chen, C.J. Elsevier, Organometallics 29 (2010) 4555;

(h) E.M. Prokopchuck, R.J. Puddhephatt, Organometallics 22 (2003) 563;

(i) T.M. Trnka, R.H. Grubbs, Acc. Chem. Res. 34 (2001) 18;

(j) T. Weskamp, V.P. Bohm, W.A. Hermann, J. Organomet. Chem. 600 (2000) 12 ;

(k) L. Jafapour, S.P. Nolan, Adv. Organomet. Chem. 46 (2000) 181.

[3] (a) H.W. Wanzlick, Angew. Chem., Int. Ed. 74 (1962) 129;

(b) H.W. Wanzlick, H.J. Kleiner, Angew. Chem. 73 (1961) 493;

(c) H.W. Wanzlick, E. Schikora, Angew. Chem. 72 (1960) 494;

(d) K Öfele, J Organomet. Chem. 12 (1968) P42.

[4] (a) A.J. Arduengo, R.L. Harllow, M.J. Kline, J. Am. Chem. Soc. 113 (1991) 361; (b) A.J. Arduengo, H.V.R. Dias, J.C. Calabrese, F. Davidson, J. Am. Chem. Soc. 114 (1992) 5530;

(c) A.J. Arduengo, H.V.R. Dias, J.C. Calabrese, F. Davidson, J. Am. Chem. Soc. 114 (1992) 9724

[5] (a) F. Visentin, A. Togni, Organometallics 26 (2007) 3746; (b) A.W. Waltman, R.H. Grubbs, Organometallics 23 (2004) 3105;

(c) H. Seo, H. Park, B.Y. Kim, J.H. Lee, Y.K. Chung, Organometallics 22 (2003) 618 ; 
(d) M. Freseth, A. Dhindsa, H. Røise, M. Tilset, J. Chem. Soc. Dalton Trans. (2003) 4516;

(e) L.G. Bonnet, R.E. Doutwhite, B.M. Kariuki, Organometallics 22 (2003) 4187; (f) A.A.D. Tulloch, S. Winston, A.A. Danoupolos, G. Eastham, M.B. Hursthouse, J. Chem. Soc. Dalton Trans. (2003) 699;

(g) A.A.D. Tulloch, A.A. Danoupolos, S. Khleinhenz, M.E. Light, M.B. Hursthouse G. Eastham, Organometallics 20 (2000) 2027;

(h) A.A.D. Tulloch, A.A. Danoupolos, S. Winston, S. Khleinhenz, G. Eastham, J. Chem. Soc. Dalton Trans. (2000) 4499.

[6] E. Negishi, Handbook of Organopalladium Chemistry for Organic Synthesis, (Sect I.2), John Wiley and Sons, New York, 2002.

[7] J. Tsuji, Palladium Reagents and Catalysis, John Wiley and Sons, Chichester, 1995.

[8] L. Canovese, F. Visentin, Inorg. Chim. Acta Rev. 363 (2010) 2375.

[9] L. Canovese, F. Visentin, C. Levi, C. Santo, V. Bertolasi, Inorg. Chim. Acta 378 (2011) 239.

[10] (a) L. Canovese, C. Santo, T. Scattolin, F. Visentin, V. Bertolasi, J. Organomet. Chem 794 (2015) 288;

(b) L. Canovese, F. Visentin, T. Scattolin, C. Santo, V. Bertolasi, Polyhedron 119 (2016) 577.

[11] (a) L. Canovese, F. Visentin, G. Chessa, P. Uguagliati, A. Dolmella, J. Organomet. Chem 601 (2000) 1:

(b) L. Canovese, F. Visentin, P. Uguagliati, B. Crociani, J. Chem. Soc. Dalton Trans. (1996) 1921.

[12] L. Canovese, F. Visentin, C. Biz, T. Scattolin, C. Santo, V. Bertolasi, Polyhedron 102 (2015) 94.

[13] L. Canovese, F. Visentin, C. Levi, C. Santo, V. Bertolasi, J. Organomet. Chem. 732 (2013) 27.

[14] L. Canovese, F. Visentin, C. Levi, C. Santo, V. Bertolasi, Inorg. Chim. Acta 390 (2012) 105.

[15] L. Canovese, F. Visentin, G. Chessa, P. Uguagliati, C. Santo, A. Dolmella, Organometallics 24 (2005) 3297.

[16] At variance with the ligand exchange which in the case of $\operatorname{Pd}(0)$ complexes is usually immediate, (See Ref. 11a) the transmetalation reactions take several seconds to be complete, as can be deduced from the observed progressive precipitation of $\mathrm{AgBr}$.

[17] L. Canovese, F. Visentin, C. Biz, T. Scattolin, C. Santo, V. Bertolasi, J. Organomet. Chem. 794 (2017) 288.

[18] M.N. Burnett, C.K. Johnson, ORTEP III, Report ORNL-6895, Oak Ridge National Laboratory, Oak Ridge, TN, 1996.
[19] (a) D.J. Daigle, T.J. Decuir, J.B. Robertson, D.J. Darensbourg, Inorg. Synth. 32 (1998) 40;

(b) A.D. Phillips, L. Gonsalvi, A. Romerosa, F. Vizza, M. Peruzzini, Coord. Chem. Rev. 248 (2004) 955;

(c) J. Bravo, S. Bolaño, L. Gonsalvi, M. Peruzzini, Coord. Chem. Rev. 254 (2010) 555;

(d) E. Guerrero, S. Miranda, S. Lüttenberg, N. Fröhlich, J. Koenen, F. Mohr, E. Cerrada, M. Laguna, A. Mendía, Inorg. Chem. 52 (2013) 6635.;

(e) M. Serrano-Ruiz, L.M. Aguilera-Sáez, P. Lorenzo-Luis, J.M. Padrón, A Romerosa, Dalton Trans. 42 (2013) 11212.

[20] Gaussian 09, M.J. Frisch, G.W. Trucks, H.B. Schlegel, G.E. Scuseria, M.A. Robb, J. R. Cheeseman, G. Scalmani, V. Barone, B. Mennucci, G.A. Petersson, H. Nakatsuji, M. Caricato, X. Li, H.P. Hratchian, A.F. Izmaylov, J. Bloino, G. Zheng, J.L. Sonnenberg, M. Hada, M. Ehara, K. Toyota, R. Fukuda, J. Hasegawa, M. Ishida, T. Nakajima, Y. Honda, O. Kitao, H. Nakai, T. Vreven, J.A. Jr. Montgomery, J.E. Peralta, F. Ogliaro, M. Bearpark, J.J. Heyd, E. Brothers, K.N. Kudin, V.N. Staroverov, R. Kobayashi, J. Normand, K. Raghavachari, A. Rendell, J. C. Burant, S.S. Iyengar, J. Tomasi, M. Cossi, N. Rega, J. M. Millam, M. Klene, J.E. Knox, J.B. Cross, V. Bakken, C. Adamo, J. Jaramillo, R. Gomperts, R.E. Stratmann, O. Yazyev, A.J. Austin, R. Cammi, C. Pomelli, J.W. Ochterski, R.L. Martin, K. Morokuma, V.G. Zakrzewski, G.A. Voth, P. Salvador, J.J. Dannenberg, S. Dapprich, A.D. Daniels, Ö. Farkas, J.B. Foresman, J.V. Ortiz, J. Cioslowski, D.J. Fox, Gaussian Inc., Wallingford, CT, 2009.

[21] L. Canovese, F. Visentin, C. Santo, A. Dolmella, J. Organomet. Chem. 694 (2009) 411.

[22] Y. Zhao, D.G. Truhlar, Acc. Chem. Res. 41 (2008) 157.

[23] F. Weigend, R. Ahlrichs, Phys. Chem. Chem. Phys. 7 (2005) 3297.

[24] (a) V. Barone, M. Cossi, J. Tomasi, J. Chem. Phys. 107 (1997) 3210; (b) V. Barone, M. Cossi, J. Phys. Chem. A 12 (1998) 1995.

[25] Z. Otwinowski, W. Minor, Methods in enzymology, in: C.W. Carter, R.M. Sweet, (Eds.), Vol. 276, Part A, Academic Press, London, (1997) 307-326.

[26] R.H. Blessing, Acta Crystallogr. Sect. A 51 (1995) 33.

[27] A. Altomare, M.C. Burla, M. Camalli, G.L. Cascarano, C. Giacovazzo, A. Guagliardi, A.G. Moliterni, G. Polidori, R. Spagna, J. Appl. Crystallogr. 32 (1999) 115.

[28] G.M. Sheldrick, Crystal Structure Refinement with SHELXL, Acta. Crystallogr. C 71 (2015) 3.

[29] M. Nardelli, J. Appl. Crystallogr. 28 (1995) 659.

[30] L.J. Farrugia, J. Appl. Crystallogr. 32 (1999) 837. 